Review

\title{
Deviant Behavior: Tick-Borne Pathogens and Inflammasome Signaling
}

\author{
Dana K. Shaw *, Erin E. McClure, Xiaowei Wang and Joao H. F. Pedra \\ Department of Microbiology and Immunology, University of Maryland School of Medicine, Baltimore, \\ MD 21201, USA; erin.mcclure@umaryland.edu (E.E.M.); xiwang@som.umaryland.edu (X.W.); \\ jpedra@som.umaryland.edu (J.H.F.P.) \\ * Correspondence: dshaw@som.umaryland.edu; Tel.: +1-410-706-3115
}

Academic Editor: Ulrike Munderloh

Received: 1 August 2016; Accepted: 23 September 2016; Published: 28 September 2016

\begin{abstract}
In the face of an assault, host cells mount an immediate response orchestrated by innate immunity. Two of the best described innate immune signaling networks are the Toll- and the Nod-like receptor pathways. Extensive work has been done characterizing both signaling cascades with several recent advances on the forefront of inflammasome biology. In this review, we will discuss how more commonly-studied pathogens differ from tick-transmitted microbes in the context of Nod-like receptor signaling and inflammasome formation. Because pathogens transmitted by ticks have unique characteristics, we offer the opinion that these microbes can be used to uncover novel principles of Nod-like receptor biology.
\end{abstract}

Keywords: tick-borne diseases; tick-borne pathogens; Nod-like receptors (NLR)

\section{Introduction}

Innate immunity is an important first responder to infectious assaults and has a key role in facilitating the development of an adaptive immune response. The innate immune system is able to distinguish self from non-self by surveying the host milieu for pathogen-associated molecular patterns (PAMPs) or danger-associated molecular patterns (DAMPs). The different categories of innate immune signaling are grouped according to their pattern recognition receptors, which include (1) Toll-like receptors (TLR); (2) Nod-like receptors (NLR); (3) absent in myeloma (AIM2); (4) C-type lectin receptors; (5) retinoid acid-inducible gene I-like receptors (RIG I-like) and (6) cyclic GMP-AMP synthase (cGAS)/STING (stimulator of interferon genes) [1]. Two of the best studied pathways are TLR and NLR signaling, which localize and respond to stimuli either at the plasma membrane surface or intracellularly, respectively [1,2].

The field of NLR biology is rapidly advancing [3-8]. NLR proteins are cytosolic pathogen recognition receptors (PRRs) that typically contain a protein-protein interaction domain located at the N-terminus (CARD (caspase-activation and recruitment domain), BIR (baculovirus inhibitor of apoptosis protein repeat) or PYD (pyrin domain)), a central NACHT domain or Nod (nucleotide-binding oligomerization domain) and carboxy-terminal leucine-rich repeats [2]. Nod 1/2 receptors were the first characterized members of the NLR superfamily and are both activated by different forms of peptidoglycan $[2,9,10]$. Nod1 recognizes $\gamma$-D-glutamyl-meso-diaminopimelic acid (iE-DAP) peptidoglycan, which is typically found in the cell wall of Gram-negative bacteria, although there are a few exceptions [11-13]. Nod2 recognizes and binds to muramyl dipeptide (MDP), which is found in the cell wall of both Gram-negative and -positive bacteria [10,14]. More recently, both Nod1 and Nod2 were associated with potentiating an inflammatory response after endoplasmic reticulum (ER) stress was induced by the intracellular pathogen, Brucella abortus [15]. The adapter kinase, RIPK2, transduces the signal for 
both Nod1 and Nod2, which culminates in a proinflammatory immune response mediated by the transcription factors, NF- $\mathrm{KB}$ (nuclear factor $\mathrm{\kappa}$ B) or AP1 (activator protein 1) $[2,9,16,17]$.

Other members of the NLR superfamily can oligomerize into a large, multi-protein scaffolding complex termed the "inflammasome". Generally speaking, a receptor, such as an NLR, will complex with an adaptor protein and will then oligomerize. This culminates in the activation of caspase-1, which cleaves pro-IL-1 $\beta$ and pro-IL-18 into their mature forms. The best-studied inflammasomes are NLRP3, NLRC4, AIM2 and the noncanonical inflammasome perpetuated by caspase-11. NLRP3 inflammasomes require an NF-kB-dependent priming step, propagated by either TLR or Nod ligands, to initiate transcription of $n l r p 3$ [18]. The NLRP3 inflammasome contains an N-terminal PYD domain, typically requires the adapter protein ASC (apoptosis speck-like protein containing a caspase activation and recruitment domain) and is activated by a variety of stimuli, including viral infections [19], fungal products [20], bacterial RNA and DNA [21-23], numerous secreted bacterial products [18,24,25], crystalline or particulate matter [26-28], serum amyloid A and endogenous danger signals, such as ATP $[24,29]$. A variety of critical upstream signals have been implicated in NLRP3 activation, such as potassium efflux, fluctuations in cell volume, calcium signaling, lysosomal damage and the production of reactive oxygen species $[25,28,30-40]$.

The NLRC4 inflammasome does not associate with ASC and instead complexes with NAIP molecules (NLR family, apoptosis inhibitor proteins) [3,18,41]. Upon stimulation, NAIP molecules and NLRC4 assemble into a high molecular weight, ring-shaped oligomer. Pro-caspase-1 is activated through interactions with the C-terminal CARD domain of NLRC4, which then cleaves pro-IL-1 $\beta$ and pro-IL-18 and induces an inflammatory form of cell death, termed pyroptosis $[4,42,43]$. Although there is only one NAIP encoded in the human genome, there are seven currently-known mouse NAIPs (NAIP1-7), which likely arose from gene duplication events $[3,18,41]$. Known stimuli that activate the NLRC4 inflammasome include flagellin (NAIP5/6) and components of the bacterial type 3 secretion systems (T3SS), such as the needle protein (NAIP1) and inner rod proteins (NAIP2). Ligands for the other NAIPs (NAIP3, 4 and 7) and their role in inflammasome activation are currently unknown $[3,18,24,41]$.

Although not a NLR protein, the AIM2 inflammatory complex is one of the better understood inflammasomes, which recognizes cytosolic, double-stranded DNA [24,44]. AIM2 molecules have a positively-charged C-terminal HIN-200 domain, which complexes with negatively-charged double-stranded DNA, and an N-terminal PYD domain, which recruits the adapter molecule, ASC, through PYD-PYD interactions. The CARD-domain of ASC then activates procaspase- 1 to induce cleavage of pro-IL-1 $\beta$ and pro-IL-18 [24,41]. The AIM2 inflammasome is negatively regulated by the p202 protein, which has two HIN200 domains, but which lacks a PYD domain $[45,46]$.

Another more recently-identified pathway is the noncanonical inflammasome, which senses lipopolysaccharide (LPS) independent of TLRs. Cytosolic LPS binds directly to caspase-11 (mice) or caspase-4/5 (human), causing activation of caspase-1, secretion of IL-1 $\beta$ and IL-18 and pyroptosis [47]. Gasdermin D was recently identified to be downstream from caspase- 11 and caspase- 1 activation and to be required for both secretion of IL-1 $\beta$ and IL-18 and induction of pyroptosis [7,8,48,49]. Gasdermin $\mathrm{D}$ is cleaved by proinflammatory caspases and then forms pores from within the cell, thereby causing endogenous cell lysis, but not causing harm to neighboring cells $[7,8]$. Gasdermin D was also able to form pores in bacterial cell membranes, which may imply a role for the direct killing of cytosolic bacteria, although the precise role of this function remains unknown $[7,8]$.

It is clear that inflammasome formation is crucial for host cells to sense and respond to cytosolic microbes, antigens and/or endogenous danger signals. The rapidly-advancing field of inflammasome biology highlights the complexity and importance of innate immunity. Recent advances have contributed tremendously towards our understanding. However, the field is somewhat skewed, owing to the types of microbes that have classically been used in inflammasome research. We hypothesize that there are unknown aspects of inflammasome biology, which may be elucidated in the context of infection with uncommon pathogens. 
Pathogens that are transmitted by ticks are fundamentally different than some other, more commonly-studied microbes with regard to physiology, induced pathology and life strategy. For example, several tick-borne bacteria do not have canonical PAMPs, such as LPS (Borrelia spp., Anaplasma spp. and Ehrlichia spp.) or have modified versions that are not efficiently recognized by host PRRs (Francisella spp.) [50-54]. Many also induce a milder version of disease than what is seen from pathogens commonly used in inflammasome research. For instance, B. burgdorferi infects mammals and can cause persistent disease symptoms, but is not considered lethal $[55,56]$. Instead, these bacteria aim to avoid immune recognition, but not kill the host. This is likely a necessity given their life strategy, which involves the cyclic transmission between host and arthropod vector.

Herein, we offer the opinion that inflammasome responses differ between pathogens that are more commonly studied and tick-borne microbes. For the purpose of this review, we have selected a small subset of microbes to discuss in the context of inflammasome biology: two Gram-negative bacteria (Salmonella spp. and Legionella pneumophila), a genus of acid-fast bacteria (Mycobacterium spp.), obligate intracellular bacteria that are not vectored by arthropods (Chlamydia spp.) and a vector-borne parasite (Plasmodium spp.). These will be directly compared to five well-known tick-transmitted bacteria: Anaplasma spp., Ehrlichia spp., Borrelia spp., Rickettsia spp. and Francisella spp. Due to space constraints, this review will focus primarily on the most well-studied inflammasomes. For further details on inflammasome signaling in response to additional pathogens, please refer to Table 1. 
Table 1. Pathogens and associated agonists that elicit inflammasome activation.

\begin{tabular}{|c|c|c|c|c|c|}
\hline Microbe & Organism & Gram Staining OR Phylogeny & Inflammasome & Agonist & References \\
\hline \multirow{14}{*}{ Bacteria } & Mycobacterium spp. & Acid-fast & NLRP3, AIM2 & $\begin{array}{l}\text { ATP, ESX-1, K+ efflux, ROS, DNA, cathepsin B release, } \\
\text { lysosomal acidification }\end{array}$ & [57-60] \\
\hline & Bacillus anthracis & Gram-positive & NLRP1 & Lethal factor, $\mathrm{K}+$ efflux & [61-66] \\
\hline & Chlamydia spp. & Gram-negative & NLRP3 & K+ efflux, cathepsin B release, ROS & [67-69] \\
\hline & Salmonella spp. & Gram-negative & NLRC4, NLRP3 & Flagellin, rod (PrgJ) and needle proteins & {$[4,18,70-74]$} \\
\hline & Legionella pneumophila & Gram-negative & NLRC4, NLRP3 & Flagellin, T4SS effectors & {$[71,75-89]$} \\
\hline & Shigella flexneri & Gram-negative & NLRC4, NLRP3 & Flagellin, MixI toxin & [90-93] \\
\hline & $\begin{array}{c}\text { Enterohemorrhagic and } \\
\text { Enteropathogenic Escherichia coli }\end{array}$ & Gram-negative & NLRP3 & T3SS effectors, cytoplasmic mRNA, NleA and NleE & {$[21,94-98]$} \\
\hline & Pseudomonas aeruginosa & Gram-negative & NLRC4 & Flagellin, mitochondrial DNA & [99-103] \\
\hline & Listeria monocytogenes & Gram-positive & NLRC4, NLRP3, AIM2 & Flagellin, DNA, listeriolysin $\mathrm{O}$ & [104-106] \\
\hline & Anaplasma phagocytophilum & Gram-negative & NLRC4 & Unknown & {$[5,107-110]$} \\
\hline & Borrelia burgdorferi & Gram-negative & $\begin{array}{l}\text { Unknown. ASC and } \\
\text { caspase- } 1 \text { dependent }\end{array}$ & Unknown & [111-114] \\
\hline & Ehrlichia spp. & Gram-negative & NLRP3, caspase-11 & Unknown & {$[115,116]$} \\
\hline & Francisella spp. & Gram-negative & AIM2 & dsDNA & {$[117,118]$} \\
\hline & Rickettsia spp. & Gram-negative & NLRP3 & Unknown & [119] \\
\hline \multirow{4}{*}{ Parasites } & Leishmania spp. & Kinetoplastid; vector-borne & NLRP3 & K+ efflux, cathepsin B, Syk-mediated ROS production & [120-122] \\
\hline & Trypanosoma cruzi & Kinetoplastid; vector-borne & NLRP3 & Lysosomal damage, ROS, K+ efflux & {$[123,124]$} \\
\hline & Plasmodium spp. & Apicomplexan; vector-borne & NLRP3, AIM2, NLRP12 & Hemozoin, K+ efflux, free heme, ROS production, DNA & [125-129] \\
\hline & Schistosoma mansoni & Helminth & NLRP3 & ROS production, $\mathrm{K}+$ efflux & {$[130,131]$} \\
\hline \multirow{10}{*}{ Viruses } & Hepatitis B virus (HBV) & Hepadnaviridae; dsDNA-RT & AIM2 & viral dsDNA & [132] \\
\hline & Hepatitis $\mathrm{C}$ virus $(\mathrm{HCV})$ & Flavivirus; (+) RNA genome & NLRP3 & K+ efflux, ROS & [133-135] \\
\hline & Vaccinia & Orthopoxvirus; dsDNA genome & AIM2 & viral dsDNA & [136] \\
\hline & Respiratory syncytial virus (RSV) & Pneumovirus; (-) RNA genome & NLRP3 & ROS, K+ efflux & [137] \\
\hline & Rhinovirus & Enterovirus; (+) RNA genome & NLRP3, NLRC5 & Ion channel protein 2B & [138] \\
\hline & Dengue virus (DENV) & Flavivirus; vector-borne & NLRP3 & ROS & {$[139,140]$} \\
\hline & Chikungunya virus (CHIKV) & Alphavirus; vector-borne & AIM2, NLRP3 & Unknown & [141,142] \\
\hline & $\begin{array}{l}\text { Human immunodeficiency } \\
\text { virus } 1 \text { (HIV-1) }\end{array}$ & Lentivirus; (+) RNA genome & NLRP3 & Cathepsin B, ROS, K+ efflux & {$[135,143-145]$} \\
\hline & Influenza A (IAV) & $\begin{array}{l}\text { Influenza virus A; } \\
(-) \text { RNA genome }\end{array}$ & NLRP3 & ROS, lysosomal maturation, $\mathrm{K}+$ efflux & {$[22,146,147]$} \\
\hline & Herpes simplex virus 1 (HSV-1) & Simplex virus; dsDNA & NLRP3, AIM2 & dsDNA & {$[23,148]$} \\
\hline
\end{tabular}




\section{Pathogens that Stimulate NLR Signaling}

\subsection{Salmonella spp.}

Salmonella spp. are Gram-negative bacteria that are transmitted to a host via a fecal-oral route [149]. Infection is initiated by host cell invasion and replication with an endosomal compartment termed the Salmonella-containing vacuole (SCV), although cytosolic replication within some cell types has also been reported. This bacterium has several potent stimulators of NLR-mediated immunity, including LPS, flagellin and a T3SS [70]. Inflammasome activation against Salmonella has been extensively studied both in vitro and in vivo in recent years. The presence of LPS primes the NLRP3 inflammasome by stimulating TLR4 and inducing NF-kB-mediated transcription of both $n l r p 3$ and pro-IL-1 $[4]$. Flagellin and components of the T3SS (needle and rod proteins) stimulate the formation of the NLRC4 inflammasome and caspase- 1 activation through recognition by NAIP adapter proteins [18]. Although there are discrepancies in the number of NAIPs between mice and humans, both are capable of recognizing and responding to the T3SS needle proteins and flagellin [71-73]. Of particular interest is the recent study published by Qu et al. providing evidence for cross-talk between NLRC4 and NLRP3 inflammasomes during $S$. typhimurium infection, which were previously believed to function independently [74]. In this study, NLRP3 is recruited to the inflammasome via the NLRC4 NACHT domain. This induces a hypothesized conformational change within NLRP3, which recruits ASC and amplifies caspase-1 activation [74].

\subsection{L. pneumophila}

L. pneumophila is a facultative intracellular, Gram-negative bacterium that is commonly found in aquatic reservoirs and exists in the environment by infecting amoeba [150-152]. If these water sources become aerosolized, L. pneumophila can become an accidental pathogen through inhalation and subsequent infection of alveolar macrophages $[153,154]$. L. pneumophila replicates intracellularly within an endocytic compartment and manipulates host cell biology to promote survival by injecting a plethora of effectors with the Dot/Icm (defective for organelle trafficking/intracellular multiplication) type 4 secretion system (T4SS) [155].

The NAIP5/NLRC4 inflammasome is induced in response to L. pneumophila flagellin and T4SS effectors, triggering a robust amount of IL-1 $\beta$, IL-18 and pyroptosis [71,75-83]. In order for the inflammasome to be initiated, the T4SS must be intact, suggesting that flagellin may be secreted from the T4SS, although this has not yet been experimentally proven [75]. The NAIP5/NLRC4 inflammasome controls L. pneumophila infection with a number of mechanisms including enhanced fusion of L. pneumophila-containing vacuole with lysosomes, as well as flagellin-dependent activation of caspase-7, which leads to lysosome-mediated degradation of L. pneumophila $[84,85,156]$. In addition to the NAIP5/NLRC4, the ASC/NLRP3 inflammasome is also activated, although the L. pneumophila-derived agonist is not yet known [87-89].

Lastly, the non-canonical caspase-11-dependent inflammasome is also activated by L. pneumophila independently of flagellin, but dependent on cytosolic access of the T4SS. This inflammasome requires prior MyD88 (myeloid differentiation primary response gene 88) and TRIF (TIR-domain-containing adapter-inducing interferon- $\beta$ )-induced upregulation of caspase-11, which leads to rapid induction of pyroptosis and the release of proinflammatory cytokines IL-1 $\alpha$, IL-1 $\beta$ and IL-18 [88,89]. Once induced, NLRP3-dependent caspase-1 activation, NAIP5/NLRC4 inflammasome activation and phagolysosomal fusion with the L. pneumophila-containing vacuole are enhanced $[88,89,156]$. Caspase-11 can also be activated by L. pneumophila that aberrantly enters the cytosol, likely through the recognition of LPS [157-159]. This was shown through the use of a mutant lacking the SdhA effector, which is needed for maintaining the integrity of the L. pneumophila-containing vacuole [157]. As such, the physiological relevance of this experimental model to naturally occurring infectious conditions is not clear, but can be used to understand host inflammatory processes. The $\Delta s d h A$ mutated bacteria are rapidly degraded, releasing double-strand DNA into the cytosol, which activates 
the AIM2 inflammasome and releases IL-1 $\beta$. Pyroptosis is also triggered by this mutant, but is mediated by caspase-11 activation [157-160].

\subsection{Chlamydia spp.}

Chlamydia spp. are classified as Gram-negative and are obligate intracellular, non-flagellated bacteria that replicate within a membrane-bound endocytic compartment. Depending on the species, Chlamydia have a narrow range of hosts they are adapted to infect [161]. The two best studied human-adapted species are C. trachomatis and C. pneumoniae that each exhibit distinct pathologies. C. pneumoniae invades alveolar epithelial cells and macrophages, while C. trachomatis predominantly infects epithelial cells [162,163]. Host cells are manipulated by Chlamydia effector molecules secreted into the cytosol via a T3SS [164].

Caspase-1 activation and associated proinflammatory cytokine secretion during C. trachomatis infection in epithelial cells have been reported to be dependent on ASC and NLRP3, which are activated in response to potassium efflux from the cytosol, lysosomal acidification and cathepsin B release resulting from lysosomal damage [69]. However, the kinetics of inflammasome activation, how this correlates with the phase of infection, whether there is an associated benefit or detriment to the microbe and if there are variations between strains are details that are less well defined. In vitro, fibroblasts deficient in asc and caspase-1 are resistant to C. trachomatis infection [165]. Conversely, using an in vivo infection model with the mouse-adapted species C. muridarum, both caspase-1/- and wild-type mice controlled bacterial burden comparably, although caspase $-1^{-/-}$mice had less inflammatory damage in the urogenital tract, suggesting that inflammasome activation contributes to pathology [166].

Another study performed by Abdul-Sater et al. suggested that stage-specific activation of caspase-1 directly impacted the detriment or benefit to Chlamydia spp. [67]. In an epithelial cell infection model with $C$. trachomatis, the translocated microbial effector Chlamydial protease-like activity factor (CPAF) inhibits ASC and caspase-1 at early time points during infection, which promoted host cell survival [165]. However, if caspase-1 was pharmacologically inhibited later in infection, bacterial replication was restricted [67]. This suggests that the kinetics of inflammasome activation can directly influence the survival of infectious microbes and the resulting pathology from disease. Moreover, it appears that pathogenic microbes can target and manipulate the kinetics of inflammasome activation to facilitate survival.

A 2015 study published by Finethy et al. proposed a model where guanylate binding proteins (GBPs) promote activation of NLRP3 and the noncanonical caspase-11-dependent inflammasomes during Chlamydia infection [167]. This study differentially primed macrophages with either IFN- $\gamma$ or LPS and saw variations in cytokine profiles during early infection (eight hours). IL-18 secretion was dependent on the presence of GBPs, regardless of which priming agent was used (IFN- $\gamma$ vs. LPS). However, GBPs were only required for secretion of IL-1 $\beta$ under LPS priming conditions and were dispensable for IFN- $\gamma$ priming [167]. These results demonstrate that GBPs influence the kinetics of inflammasome activation and alter the relative amounts of secreted IL-1 $\beta$ and IL-18, which may affect the resulting pathology from Chlamydia infection [167].

\subsection{Mycobacterium spp.}

Mycobacterium spp. are acid fast bacteria with a thick cell wall consisting of mycolic acid and peptidoglycan, which contributes to the hardiness of this genus [168]. While Mycobacterium spp. can be environmental or pathogenic bacteria, the most well-known is the tuberculosis-causing species, M. tuberculosis. This pathogen enters host alveolar macrophages and replicates within an endosomal compartment by manipulating host cells with secreted effectors that prevent lysosomal fusion $[169,170]$. The involvement of IL-1 $\beta$ in host defense against $M$. tuberculosis is well established as both $i l-1 \beta$ or $i l-1$ receptor (ifnar1) knockout mice are more susceptible to infection [171-174]. In the lungs of infected ifnar $^{-/-}$mice, there is a two log-fold increase in bacteria and necrotic pneumonia develops within four 
weeks [174]. IL-18 also has an important role, as $i l-18^{-/-}$mice were more susceptible to $M$. tuberculosis infection, but not il-18 receptor knockouts [175].

NLRP3 has previously been implicated as the sole NLR in sensing $M$. tuberculosis infection, triggered by potassium depletion [176-181]. Non-tuberculous mycobacteria also stimulate NLRP3 activation, although through different mechanisms (lysosomal acidification, ROS production and cathepsin B release) [178]. The lack of AIM2 inflammasome activation during M. tuberculosis infection was historically perplexing because the Mycobacterium type VII secretion system, ESX-1, translocates DNA into the host cell cytosol [176]. However, in 2012, Saiga et al. reported that aim2 knockout mice infected with $M$. tuberculosis had decreased levels of IL-1 $\beta$ and IL-18 in the lungs, suggesting that AIM2 was indeed activated [182]. In 2012, Yang et al. demonstrated that a virulent strain of $M$. bovis activated the AIM2 inflammasome from a murine-derived macrophage cell line [59], and Shah et al. observed that non-tuberculous mycobacteria elicited the AIM2 inflammasome in an ESX-1 dependent manner [183]. Interestingly, when macrophages were co-infected with M. tuberculosis and a non-tuberculous mycobacteria (M. smegmatis), the AIM2 inflammasome was suppressed [183]. This evidence suggests that Mycobacteria do activate the AIM2 inflammasome, but that tuberculosis-causing Mycobacteria have a secreted factor that suppresses inflammasome activation [176,183].

Cellular immunity has historically been considered the hallmark of immune-mediated protection against $M$. tuberculosis. These studies challenge this dogma and demonstrate that cellular-mediated immunity is not sufficient for protection, as particularly demonstrated with the $i l-1$ receptor knockout mice that caused an increase in bacterial burden $[174,184]$. This may be attributable to the role IL- $1 \beta$ plays in promoting the differentiation of CD4 T cells into the Th17 subtype, which have a critical role in generating an anti-M. tuberculosis response in addition to Th1 cells [184-187].

\subsection{Plasmodium spp.}

A hallmark of malaria pathology is the cyclic fevers that coincide with rupturing red blood cells that release merozoites during the blood stage of Plasmodium infection and induce a cytokine storm [188]. Proinflammatory cytokines, such as IFN- $\gamma$, TNF- $\alpha$, IL-12 and, importantly, IL-1 $\beta$, are produced, implicating inflammasome involvement during malaria infection [189-191]. Indeed, several studies have reported NLRP3 inflammasome activation, although determining the agonist has been a contentious topic $[125,126,128]$. Hemozoin is an inorganic crystal produced by Plasmodium during the heme detoxification process and has been suggested to induce the inflammasome [192]. It is released from infected erythrocytes during the asexual stage of parasite reproduction (schizogony) and has been reported to activate NLRP3 and stimulate TLR9 [193,194]. Kalantari et al. linked hemozoin to both NLRP3 and AIM2 inflammasomes [128]. NLRP3 was reportedly activated by hemozoin-induced vacuolar lysis, and the subsequent cytosolic location of hemozoin, which is bound by Plasmodium DNA, then stimulated the AIM2 inflammasome [128]. Whether or not the NLRP3 inflammasome contributes to malaria pathology and parasitemia has also been debated. A 2009 study published that the NLRP3 inflammasome contributes to cerebral malaria, but does not influence parasitemia [126]. Other groups have reported that, while Plasmodium infection stimulates NLRP3, mouse mortality caused by cerebral malaria and parasitemia were not influenced by the inflammasome [195-197].

Nevertheless, inflammasome induction caused by Plasmodium infection is indisputable. Compelling evidence for inflammasome involvement during human infection was provided in a study by Ataide et al., which showed that different subsets of patient-derived monocytes infected with either P. vivax or P. falciparum had activated forms of caspase- 1 and elevated levels of secreted IL-1 $\beta$ [127]. Moreover, this same study demonstrated that increased expression of inflammasome genes, such as caspase- 1 and $i l-1 \beta$, were found in a $P$. chabaudi AS rodent model and correlated these phenotypes to NLRP3 and NLRP12 activation [127]. Although involvement of the inflammasome did not appear to influence the development of parasitemia or mouse survival, it did cause hypersensitivity to low doses of LPS when mice were subjected to a secondary challenge [127]. This is particularly 
relevant given that, in clinical settings, Plasmodium-infected patients are highly susceptible to a lethal septic-shock-like syndrome caused by bacterial infections [198-200].

\section{Tick-Transmitted Microbes}

Ticks are an ancient lineage of arthropod that diverged from insects approximately 450 million years ago. These arachnids have unique features that distinguish them from other arthropods, such as an extended life span (up to 10 years is some species) and an exclusively hematophagous diet. Lifestyle and physiology are contributing factors that allow ticks to harbor and transmit multiple pathogens of human and veterinary relevance. For example, the deer tick, Ixodes scapularis, can transmit up to six different pathogens, including intra- and extra-cellular bacteria, viruses and protozoa (A. phagocytophilum, an E. muris-like bacterium, B. burgdorferi, B. miyamotoi, Powassan virus, Babesia microti) [201].

Microbes that are vectored by ticks tend to deviate in life strategy and general biology from other classically-studied pathogens. Tick-borne microbes oscillate between two different environments (arthropod vs. vertebrate host) and therefore must be capable of sensing and responding to a variety of stimuli, such as fluctuations in temperature, $\mathrm{pH}$, nutrient availability, dissolved oxygen levels and other undefined host/tick-specific components [202-219]. Moreover, several of these microbes have unusual physiological features, such as varied forms of LPS and peptidoglycan or the lack of LPS and peptidoglycan altogether. This is likely a reflection of the long co-evolutionary relationship that tick-borne pathogens have with the tick itself [220-222]. Instead, many incorporate lipids, cholesterol and lipoproteins for structural support of the cell wall $[51,223,224]$. These characteristics are dissimilar from typical PAMPs found on other microbes; therefore, host immune surveillance mechanisms and responses also differ from classically-described principles in immunology.

It is important to note that there are multiple variables that intermix and influence pathogen transmission of tick-borne diseases. One of the best studied variables is tick saliva and the role it has in suppressing localized host immune response. There is an extensive body of work examining the effect of tick saliva on both cellular and humoral immunity and how this ultimately influences the transmission of tick-borne microbes [225-227]. Saliva is crucial for promoting the prolonged feeding behavior exhibited by ticks. Effects exerted on a host by tick saliva include inhibiting itch responses, preventing blood vessel constriction and coagulation, skewing cytokine production profiles, deterring immune cell migration and differentiation and blocking wound healing [222,225,226,228-258]. Another more recently-published study elucidated a molecular mechanism that the tick salivary protein, sialostatin L2, has for inhibiting inflammasome formation [5]. The immunosuppressive properties of tick saliva inadvertently promote pathogen transmission to a host [227,259-265]. This is an important aspect to studying tick-borne microbes and understanding their life strategy. However, due to the space constraints of this review, we will limit our focus to tick-transmitted pathogens in the context of NLR and inflammasome signaling. More discussion on the immunosuppressive properties of tick saliva can be found in the following reviews [225-227,266,267].

\subsection{Anaplasma spp. and Ehrlichia spp.}

Both Anaplasma spp. and Ehrlichia spp. (order: Rickettsiales; family: Anaplasmataceae) are obligate intracellular bacteria that reside and replicate within an endosomal compartment that does not fuse with the lysosome. Generally speaking, Anaplasma spp. are transmitted by Ixodes spp. of ticks (scapularis, ricinus, pacificus and persulcatus), and Ehrlichia spp. can be transmitted by Amblyomma americanum (E. chaffeensis) and I. scapularis (E. muris-like) ticks $[201,267,268]$. Neither of these two bacteria have PAMPs that are known to bind Nod1/2 receptors or induce inflammasome activation; nevertheless, studies have reported that both induce NLR signaling.

A 2012 study by Sukumaran et al. demonstrated that RIPK2 (receptor interacting protein-2), the adapter kinase for Nod1/2 signaling, was a key regulator of the immune response to A. phagocytophilum infection in mice. Following A. phagocytophilum infection, ripk 2 transcripts were 
significantly induced above background levels. Moreover, ripk2 knockout mice were more susceptible to infection with higher bacterial burdens, less production of pro-inflammatory cytokines, IFN- $\gamma$ and IL-18, and took longer to clear A. phagocytophilum [108]. Subsequent studies demonstrated that A. phagocytophilum activates the caspase-1-dependent NLRC4 inflammasome in a manner that is reliant on annexin A2 [5]. Blocking this signaling axis by either mitigating signaling components or blocking with the tick salivary protein, sialostatin L2 (SL2), resulted in decreased caspase-1 activation and ablation of secreted IL-1 $\beta$ and IL-18 during A. phagocytophilum infection. Interestingly, these studies also demonstrated an immunosuppressive role for tick salivary proteins that are beneficial for survival and immune subversion of $A$. phagocytophilum in host cells $[5,109,110]$.

A second study examining the mechanistic interactions between $A$. phagocytophilum and the NLRC4 inflammasome was reported recently by Wang et al. [107]. This study built on the knowledge of the annexin A2-dependent NLRC4 inflammasome triggered by A. phagocytophilum and demonstrated that signal transduction was dependent on the prostaglandin E2 (PGE2)-EP3 receptor axis. Upon infection, A. phagocytophilum activates phospholipase A2, which cleaves arachidonic acid from membrane phospholipids. Arachidonic acid is then converted to PGE2 via cyclooxygenase 2 (COX2) and the membrane-associated prostaglandin E synthase-1 (mPGES-1). EP3 receptor expression is upregulated in response to A. phagocytophilum infection, which subsequently binds PGE2 and propagates NLRC4 inflammasome activation and secretion of IL-1 $\beta$ and IL-18. In agreement with previous findings, RIPK2 was determined to be a major regulator of the immune response against A. phagocytophilum infection, and the loss of ripk2 caused ablation of NF- $\mathrm{KB}$ and NLRC4 activation [107]. Importantly, this study demonstrated a divergence in NLRC4 pathway activation from what has been previously defined with other microbes.

Two recent studies have reported that Ehrlichia spp. trigger NLR signaling, which contributes to the pathology observed during fatal ehrlichiosis. Chattoraj and colleagues observed that in a murine model at seven days post-infection with the lethal ehrlichiosis-inducing isolate, Ixodes ovatus Ehrlichia, there was significant upregulation of genes involved in Nod-like receptor signaling (nod2, nf-KB, $n l r p 1, n l r p 12$, pycard and $i l-1 \beta)$, as well as Toll-like receptor 2 (tlr2). Interestingly, these two signaling pathways appeared to have opposing effects on the severity of disease. Mitigation of TLR2 enhanced tissue necrosis in mice and impaired bacterial clearance, whereas loss of Nod2 led to decreased pathology, faster clearance of infection and increases in IL-10 and IFN- $\gamma$ [115]. A later study published by the same group demonstrated that fatal ehrlichiosis led to increased activation of caspase- 1 and caspase- 11 and increased secretion of IL-1 $\beta$, IL-1 $\alpha$ and IFN-I. Caspase- 1 knockout mice were highly susceptible to disease with extensive tissue injury and increased bacterial burden. $\mathrm{Nlrp3}^{-/-}$mice showed similar liver damage and mortality rates when compared to wild-type mice, but had decreased bacterial burden. The authors ultimately found a role for IFN-I in regulating inflammasome signaling during Ehrlichia infection, which appears to regulate caspase-11 activation and therefore caspase- 1 dependent secretion of IL-1 $\beta$ [116]. Mice lacking the IFN-I receptor (ifnar1) were resistant to fatal disease, had lower bacterial burdens, decreased pathology and prolonged survival. The authors note that mutation of ifnar1 during Ehrlichia infection led to increased autophagosomal processing. Because autophagy is a known reciprocal mechanism for regulating inflammasome activation, they hypothesize that autophagy is blocked during fatal ehrlichiosis, which leads to increased bacterial burden and pathology, owing to inflammasome activation mediated by IFNAR1 and NLRP3 signaling [116].

\subsection{Rickettsia spp.}

Rickettsia spp. are obligate intracellular organisms under the order Rickettsiales, but are grouped into the family Rickettsiaceae. There are several types of ticks that transmit disease-causing Rickettsia. Rocky Mountain spotted fever Rickettsia are transmitted by Dermacentor andersoni, D. variabilis, Amblyomma spp. and Rhipicephalus sanguineus, whereas Mediterranean spotted fever-causing bacteria are transmitted by only R. sanguineus. Unlike Ehrlichia spp. and Anaplasma spp., Rickettsia spp. escape the endosome and replicate within the cytoplasm of host cells. 
Although Rickettsia are aflagellated, it is reasonable to speculate that an inflammasome or Nod1/2 response would be elicited upon Rickettsia infection based on the following points: (1) the cytosolic location of the bacteria; (2) the presence of both peptidoglycan and LPS in the Rickettsia cell wall, which are known stimulants of Nod1/2 and the caspase-11/4/5-dependent inflammasome, respectively; and (3) large amounts of secreted IL-1 $\beta$ and IL-18 from infected macrophages (119; personal observation). Very recently, Smalley et al. reported that $R$. australis does indeed activate caspase- 1 and induces the 4 secretion of IL-1 $\beta$ and IL- 18 when bone marrow-derived macrophages are infected [119]. Secretion of these pro-inflammatory cytokines was completely abrogated in cells that were deficient in caspase-1/caspase-11, asc and nlrp3. Moreover, in an infection model, $n l r p 3^{-/-}$mice were less capable of controlling bacterial burden in some tissues (spleen) when compared to wild-type mice, indicating that the NLRP3 inflammasome has a role in recognizing R. australis infection and reducing pathogen burden [119].

\subsection{Francisella spp.}

Like Rickettsia spp., Francisella spp. have peptidoglycan and LPS in the cell well and replicate within the cytosol once they have escaped the endosome [269]. However, Francisella spp. have an abnormal form of LPS that is tetra-acetylated and is therefore poorly recognized by TLR4 [54]. Among other host inoculation routes (i.e., aerosol), Francisella spp. are capable of being transmitted by $A$. americanum, $D$. andersoni and $D$. variabilis ticks. Despite the cytosolic location of these bacteria, the robust induction IL-1 $\beta$ and IL-18 upon infection and the presence of LPS and peptidoglycan in the bacterial cell membrane, there is no evidence for NLRP3, NLRC4 or noncanonical caspase-11-dependent inflammasome activation $[117,269,270]$. Instead, the AIM2 inflammasome, which is activated in response to cytosolic double-stranded DNA, is believed to respond to Francisella spp. infection. Aim 2 deficiency caused the ablation of caspase- 1 activation, IL- $1 \beta$ secretion and decreased cell death. Aim 2 knockout mice were highly susceptible to $F$. tularensis infection with increased mortality rates and higher bacterial burdens [118]. A study published by Meunier et al. in 2015 demonstrated that guanylate-binding proteins (GBP) 2 and 5 had a role in inducing the lysis of F. tularensis in the cytosol, which would expose bacterial DNA and induce the AIM2 inflammasome [117].

\subsection{Borrelia spp.}

The Lyme disease-causing bacteria, Borrelia spp., are the most prevalent tick-transmitted pathogens in the United States. It is an extracellular spirochete transmitted by ticks of the Ixodes spp. and does not have LPS, but does have peptidoglycan, albeit an uncommon form [271]. The role of inflammasome activation in response to Borrelia spp. infection has not been extensively studied, owing to the extracellular nature of these bacteria. However, the inflammatory symptoms resulting from infection has prompted a few studies to examine whether inflammasome induction contributes to the pathology of Lyme disease.

In 2008, Cruz et al. reported that live B. burgdorferi spirochetes stimulated the release of IL-1 $\beta$, which was significantly higher when compared to heat-killed bacteria [111]. These results suggested that the inflammasome could be activated in response to B. burgdorferi infection. A study reported by Liu et al. in 2009 examined the role that caspase-1 and ASC had during B. burgdorferi infection. Although the absence of caspase- 1 during systemic murine infection caused an increase in bacteria burden and in the prevalence of arthritis at Day 7, these phenotypes were resolved by Day 14 [112]. In agreement with the findings from Liu et al., another group (Oosting et al.) reported caspase- 1 activation in response to $B$. burgdorferi infection and secretion of IL-1 $\beta$ [113]. In contrast, however, this study demonstrated that capase- 1 had a significant role in determining the level of joint inflammation following B. burgdorferi infection, characterized by cellular influx and pro-inflammatory cytokine production [113]. The differences between these studies can likely be explained by variations in time post-infection and the amount of spirochetes that were used for 
inoculation. While the initial 2009 study by Liu et al. evaluated the contribution of systemic infection on joint inflammation with an intradermal inoculation route of $10^{4}$ spirochetes, the 2011 study by Oosting et al. employed an acute inflammation model that used an intra-arterial inoculation method with $10^{5}$ heat-killed spirochetes delivered directly into the joint followed by a four-hour time point, post-inoculation $[112,113]$. The same group went on to show that with the acute model of joint swelling, using intra-arterial inoculation, but with $10^{7}$ live spirochetes, was significantly affected by ASC and caspase-1, but not NLRP3 [114]. While it is clear that caspase-1 is activated in response to B. burgdorferi infection and that this regulates the secretion of IL-1 $\beta$ during infection, the physiological relevance during the natural course of systemic infection leading to late Lyme disease manifestations, such as Lyme arthritis, are still unclear.

\section{Opinion}

The role that inflammasomes have in defense against invading microbes while concomitantly assisting in the development of an adaptive immune response has been well established, and the mechanisms for sensing stimuli that lead to inflammasome activation are progressively being elucidated. A significant portion of our knowledge on the mechanistic underpinnings of inflammasome signaling has been defined using a small subset of microbes, which are often well-characterized and heavily studied. While significant advances have been made with these microbes, it skews the view of inflammasome biology and leaves some areas undefined. Examples of this are the NAIPs that complex with NLRC4. Although NAIPs1, 2 and 5/6 have characterized agonists, the role that NAIPs3, 4 and 7 have in inflammasome assembly and what their respective stimuli are remain unknown [4].

Tick-transmitted microbes tend to be very different both physiologically and in pathogenicity potential from other well-characterized pathogens. This is likely an adaptation resulting from the close co-evolutionary relationship these microbes share with ticks [220-222]. Examples of this include the lack of, or modified versions of, LPS and peptidoglycan present in many tick-borne bacteria. Moreover, some of the more commonly-studied pathogens have secretion systems that are either direct agonists themselves (the needle and rod proteins from the T3SS elicit NLRC4) or secrete effectors that are inflammasome agonists (DNA or flagellin, which activate AIM2 or NLRP3, respectively). No such components have been described for tick-borne pathogens to date. This may be attributable to the lack of experimental data examining this question in particular. Alternatively, it is possible that tick-borne pathogens have modified or a reduced number of inflammatory PAMPs. Given the immunological pressure imparted by both mammalian and arthropod environments, which recognize common PAMPs, this is a feasible possibility. The constant selective pressure may have driven the evolutionary loss of some immunogenic components.

Despite the lack of common PAMPs, inflammasome assembly is induced in response to tick-borne infections. Tick-transmitted microbes may instead elicit inflammasome activation by inducing a dysregulated state within the host cell by causing aberrant compartmentalization of molecules, proteins and/or lipids. This could be perceived as a "danger" signal. For example, A. phagocytophilum directly interferes with lysosomal maturation, can take up exogenous lipids from the environment and is hypothesized to directly parasitize lipids from the host cell to sustain growth; these activities may be sufficient to induce a danger response [50,272-276]. NLRC4 is known to respond to A. phagocytophilum infection, but is not known to respond to DAMPs [5], and as such, this may represent a novel mode of inflammasome activation.

Apart from the mechanism of activation, the downstream inflammasome signaling events also seem to differ between commonly-studied microbes and tick-borne pathogens. For instance, proinflammatory cytokine secretion resulting from inflammasome induction is linked to pyroptosis when infected with more commonly-studied pathogens [4]. A. phagocytophilum is able to induce IL-1 $\beta$ and IL-18 secretion, but curiously does not induce pyroptosis $[5,277]$. Whether this is mediated by a microbial effector molecule to suppress inflammatory cell death or if A. phagocytophilum activates an unknown inflammasome mechanism that uncouples proinflammatory cytokine secretion and 
inflammatory cell death is not yet known. This may go hand-in-hand with what we know to be true of tick-transmitted diseases, which are associated with milder versions of pathology and are not commonly lethal, in contrast to other pathogens, such as Salmonella spp., M. tuberculosis or Plasmodium. Another interesting possibility is that the timing of inflammasome induction may be either detrimental or beneficial to the microbe. This hypothesis came from the observation that the Chlamydia-secreted effector protein, CPAF, prevents pyroptosis by inhibiting ASC and caspase- 1 at early time points during infection [165]. However, if caspase-1 is blocked with pharmacological inhibitors at later time points, it restricts bacterial growth [67]. The kinetics of inflammasome activation and the correlation with the stages of intracellular bacterial replication may need to be timed correctly in order for the pathogens to establish a replicative niche and subsequently exit the host cell at an appropriate time.

With the field of inflammasome research quickly progressing, it will be enlightening to expand the arsenal of pathogenic stimuli when elucidating the mechanistic details of inflammasome formation. It is clear that there is a multitude of mechanisms for sensing inflammasome-inducing PAMPs/DAMPs, and the field has, undoubtedly, only begun to scratch the surface. By using uncommon microbes to interrogate inflammasome biology, we may be able to shed light on undiscovered mechanistic details of inflammasome activation and signal propagation, which may ultimately be correlated with disease pathology and immunological resistance to tick-borne infections.

Acknowledgments: We gratefully acknowledge Adela Oliva Chavez, Vishant Boradia and Jason M. Park for contributing their time and participating in thoughtful discussions regarding this review. This work was supported by the National Institutes of Health (R01 AI093653 and R01 AI116523 to Joao H. F. Pedra; T32AI007540 to Erin E. McClure), the University of Maryland, Baltimore School of Medicine. The content is solely the responsibility of the authors and does not necessarily represent the official views of the National Institute of Allergy and Infectious Diseases nor the National Institutes of Health.

Author Contributions: All authors contributed to the content and the preparation of this review. Dana K. Shaw wrote the manuscript, contributed to the background research and is the corresponding author. Erin E. McClure and Xiaowei Wang contributed to the background research, constructing the table, discussions, proofreading and reviewing the content. Joao H. F. Pedra conceived of the idea for this review and contributed towards the discussion, proofreading and reviewing of the content. All authors have read and approved the final version of this manuscript.

Conflicts of Interest: The authors declare no conflict of interest.

\section{References}

1. Brubaker, S.W.; Bonham, K.S.; Zanoni, I.; Kagan, J.C. Innate immune pattern recognition: A cell biological perspective. Annu. Rev. Immunol. 2015, 33, 257-290. [CrossRef] [PubMed]

2. Caruso, R.; Warner, N.; Inohara, N.; Núñez, G. NOD1 and NOD2: Signaling, host defense, and inflammatory disease. Immunity 2014, 41, 898-908. [CrossRef] [PubMed]

3. Vance, R.E. The NAIP/NLRC4 inflammasomes. Curr. Opin. Immunol. 2015, 32, 84-89. [CrossRef] [PubMed]

4. Guo, H.; Callaway, J.B.; Ting, J.P.-Y. Inflammasomes: Mechanism of action, role in disease, and therapeutics. Nat. Med. 2015, 21, 677-687. [CrossRef] [PubMed]

5. Wang, X.; Shaw, D.K.; Sakhon, O.S.; Snyder, G.A.; Sundberg, E.J.; Santambrogio, L.; Sutterwala, F.S.; Dumler, J.S.; Shirey, K.A.; Perkins, D.J.; et al. The tick protein sialostatin L2 binds to Annexin A2 and inhibits NLRC4-mediated inflammasome activation. Infect. Immun. 2016, 84, 1796-1805. [CrossRef] [PubMed]

6. Rathinam, V.A.K.; Fitzgerald, K.A. Inflammasome complexes: Emerging mechanisms and effector functions. Cell 2016, 165, 792-800. [CrossRef] [PubMed]

7. Ding, J.; Wang, K.; Liu, W.; She, Y.; Sun, Q.; Shi, J.; Sun, H.; Wang, D.-C.; Shao, F. Pore-forming activity and structural autoinhibition of the gasdermin family. Nature 2016, 535, 111-116. [CrossRef] [PubMed]

8. Liu, X.; Zhang, Z.; Ruan, J.; Pan, Y.; Magupalli, V.G.; Wu, H.; Lieberman, J. Inflammasome-activated gasdermin D causes pyroptosis by forming membrane pores. Nature 2016, 535, 153-158. [CrossRef] [PubMed]

9. Motta, V.; Soares, F.; Sun, T.; Philpott, D.J. NOD-like receptors: Versatile cytosolic sentinels. Physiol. Rev. 2015, 95, 149-178. [CrossRef] [PubMed]

10. Inohara, N.; Ogura, Y.; Chen, F.F.; Muto, A.; Nuñez, G. Human Nod1 confers responsiveness to bacterial lipopolysaccharides. J. Biol. Chem. 2001, 276, 2551-2554. [CrossRef] [PubMed] 
11. Chamaillard, M.; Hashimoto, M.; Horie, Y.; Masumoto, J.; Qiu, S.; Saab, L.; Ogura, Y.; Kawasaki, A.; Fukase, K.; Kusumoto, S.; et al. An essential role for NOD1 in host recognition of bacterial peptidoglycan containing diaminopimelic acid. Nat. Immunol. 2003, 4, 702-707. [CrossRef] [PubMed]

12. Hasegawa, M.; Yang, K.; Hashimoto, M.; Park, J.-H.; Kim, Y.-G.; Fujimoto, Y.; Nuñez, G.; Fukase, K.; Inohara, N. Differential release and distribution of Nod1 and Nod2 immunostimulatory molecules among bacterial species and environments. J. Biol. Chem. 2006, 281, 29054-29063. [CrossRef] [PubMed]

13. Girardin, S.E.; Boneca, I.G.; Carneiro, L.A.M.; Antignac, A.; Jéhanno, M.; Viala, J.; Tedin, K.; Taha, M.-K.; Labigne, A.; Zäthringer, U.; et al. Nod1 detects a unique muropeptide from Gram-negative bacterial peptidoglycan. Science 2003, 300, 1584-1587. [CrossRef] [PubMed]

14. Girardin, S.E.; Boneca, I.G.; Viala, J.; Chamaillard, M.; Labigne, A.; Thomas, G.; Philpott, D.J.; Sansonetti, P.J. Nod2 is a general sensor of peptidoglycan through muramyl dipeptide (MDP) Detection. J. Biol. Chem. 2003, 278, 8869-8872. [CrossRef] [PubMed]

15. Keestra-Gounder, A.M.; Byndloss, M.X.; Seyffert, N.; Young, B.M.; Chávez-Arroyo, A.; Tsai, A.Y.; Cevallos, S.A.; Winter, M.G.; Pham, O.H.; Tiffany, C.R.; et al. NOD1 and NOD2 signalling links ER stress with inflammation. Nature 2016, 532, 394-397. [CrossRef] [PubMed]

16. Kobayashi, K.; Inohara, N.; Hernandez, L.D.; Galán, J.E.; Núñez, G.; Janeway, C.A.; Medzhitov, R.; Flavell, R.A. RICK/Rip2/CARDIAK mediates signalling for receptors of the innate and adaptive immune systems. Nature 2002, 416, 194-199. [CrossRef] [PubMed]

17. Inohara, N.; Koseki, T.; Peso, L.; Hu, Y.; Yee, C.; Chen, S.; Carrio, R.; Merino, J.; Liu, D.; Ni, J.; et al. Nod1, an Apaf-1-like activator of Caspase-9 and Nuclear Factor-kB. J. Biol. Chem. 1999, 274, 14560-14567. [CrossRef] [PubMed]

18. Von Moltke, J.; Ayres, J.S.; Kofoed, E.M.; Chavarría-Smith, J.; Vance, R.E. Recognition of bacteria by inflammasomes. Annu. Rev. Immunol. 2013, 31, 73-106. [CrossRef] [PubMed]

19. Ichinohe, T.; Lee, H.K.; Ogura, Y.; Flavell, R.; Iwasaki, A. Inflammasome recognition of influenza virus is essential for adaptive immune responses. J. Exp. Med. 2009, 206, 79-87. [CrossRef] [PubMed]

20. Joly, S.; Sutterwala, F.S. Fungal pathogen recognition by the NLRP3 inflammasome. Virulence 2010, 1, $276-280$. [CrossRef] [PubMed]

21. Sander, L.E.; Davis, M.J.; Boekschoten, M.V.; Amsen, D.; Dascher, C.C.; Ryffel, B.; Swanson, J.A.; Müller, M.; Blander, J.M. Detection of prokaryotic mRNA signifies microbial viability and promotes immunity. Nature 2011, 474, 385-389. [CrossRef] [PubMed]

22. Kanneganti, T.-D.; Ozören, N.; Body-Malapel, M.; Amer, A.; Park, J.-H.; Franchi, L.; Whitfield, J.; Barchet, W.; Colonna, M.; Vandenabeele, P.; et al. Bacterial RNA and small antiviral compounds activate caspase-1 through cryopyrin/Nalp3. Nature 2006, 440, 233-236. [CrossRef] [PubMed]

23. Muruve, D.A.; Pétrilli, V.; Zaiss, A.K.; White, L.R.; Clark, S.A.; Ross, P.J.; Parks, R.J.; Tschopp, J. The inflammasome recognizes cytosolic microbial and host DNA and triggers an innate immune response. Nature 2008, 452, 103-107. [CrossRef] [PubMed]

24. Man, S.M.; Kanneganti, T.-D. Regulation of inflammasome activation. Immunol. Rev. 2015, $265,6-21$. [CrossRef] [PubMed]

25. Sharma, D.; Kanneganti, T.-D. The cell biology of inflammasomes: Mechanisms of inflammasome activation and regulation. J. Cell Biol. 2016, 213, 617-629. [CrossRef] [PubMed]

26. Martinon, F.; Pétrilli, V.; Mayor, A.; Tardivel, A.; Tschopp, J. Gout-associated uric acid crystals activate the NALP3 inflammasome. Nature 2006, 440, 237-241. [CrossRef] [PubMed]

27. Eisenbarth, S.C.; Colegio, O.R.; O'Connor, W.; Sutterwala, F.S.; Flavell, R.A. Crucial role for the Nalp3 inflammasome in the immunostimulatory properties of aluminium adjuvants. Nature 2008, 453, 1122-1126. [CrossRef] [PubMed]

28. Dostert, C.; Pétrilli, V.; Bruggen, R.V.; Steele, C.; Mossman, B.T.; Tschopp, J. Innate immune activation through Nalp3 inflammasome sensing of asbestos and silica. Science 2008, 320, 674-677. [CrossRef] [PubMed]

29. Mariathasan, S.; Weiss, D.S.; Newton, K.; McBride, J.; O’Rourke, K.; Roose-Girma, M.; Lee, W.P.; Weinrauch, Y.; Monack, D.M.; Dixit, V.M. Cryopyrin activates the inflammasome in response to toxins and ATP. Nature 2006, 440, 228-232. [CrossRef] [PubMed]

30. Cruz, C.M.; Rinna, A.; Forman, H.J.; Ventura, A.L.M.; Persechini, P.M.; Ojcius, D.M. ATP activates a reactive oxygen species-dependent oxidative stress response and secretion of proinflammatory cytokines in macrophages. J. Biol. Chem. 2007, 282, 2871-2879. [CrossRef] [PubMed] 
31. Pétrilli, V.; Papin, S.; Dostert, C.; Mayor, A.; Martinon, F.; Tschopp, J. Activation of the NALP3 inflammasome is triggered by low intracellular potassium concentration. Cell Death Differ. 2007, 14, 1583-1589. [CrossRef] [PubMed]

32. Cassel, S.L.; Eisenbarth, S.C.; Iyer, S.S.; Sadler, J.J.; Colegio, O.R.; Tephly, L.A.; Carter, A.B.; Rothman, P.B.; Flavell, R.A.; Sutterwala, F.S. The Nalp3 inflammasome is essential for the development of silicosis. Proc. Natl. Acad. Sci. USA 2008, 105, 9035-9040. [CrossRef] [PubMed]

33. Halle, A.; Hornung, V.; Petzold, G.C.; Stewart, C.R.; Monks, B.G.; Reinheckel, T.; Fitzgerald, K.A.; Latz, E.; Moore, K.J.; Golenbock, D.T. The NALP3 inflammasome is involved in the innate immune response to amyloid- $\beta$. Nat. Immunol. 2008, 9, 857-865. [CrossRef] [PubMed]

34. Hornung, V.; Bauernfeind, F.; Halle, A.; Samstad, E.O.; Kono, H.; Rock, K.L.; Fitzgerald, K.A.; Latz, E. Silica crystals and aluminum salts activate the NALP3 inflammasome through phagosomal destabilization. Nat. Immunol. 2008, 9, 847-856. [CrossRef] [PubMed]

35. Schorn, C.; Frey, B.; Lauber, K.; Janko, C.; Strysio, M.; Keppeler, H.; Gaipl, U.S.; Voll, R.E.; Springer, E.; Munoz, L.E.; et al. Sodium overload and water influx activate the NALP3 inflammasome. J. Biol. Chem. 2011, 286, 35-41. [CrossRef] [PubMed]

36. Zhou, R.; Yazdi, A.S.; Menu, P.; Tschopp, J. A role for mitochondria in NLRP3 inflammasome activation. Nature 2011, 469, 221-225. [CrossRef] [PubMed]

37. Compan, V.; Baroja-Mazo, A.; López-Castejón, G.; Gomez, A.I.; Martínez, C.M.; Angosto, D.; Montero, M.T.; Herranz, A.S.; Bazán, E.; Reimers, D.; et al. Cell volume regulation modulates NLRP3 inflammasome activation. Immunity 2012, 37, 487-500. [CrossRef] [PubMed]

38. Lee, G.-S.; Subramanian, N.; Kim, A.I.; Aksentijevich, I.; Goldbach-Mansky, R.; Sacks, D.B.; Germain, R.N.; Kastner, D.L.; Chae, J.J. The calcium-sensing receptor regulates the NLRP3 inflammasome through $\mathrm{Ca}^{2+}$ and cAMP. Nature 2012, 492, 123-127. [CrossRef] [PubMed]

39. Murakami, T.; Ockinger, J.; Yu, J.; Byles, V.; McColl, A.; Hofer, A.M.; Horng, T. Critical role for calcium mobilization in activation of the NLRP3 inflammasome. Proc. Natl. Acad. Sci. USA 2012, 109, 11282-11287. [CrossRef] [PubMed]

40. Muñoz-Planillo, R.; Kuffa, P.; Martínez-Colón, G.; Smith, B.L.; Rajendiran, T.M.; Núñez, G. K ${ }^{+}$efflux is the common trigger of NLRP3 inflammasome activation by bacterial toxins and particulate matter. Immunity 2013, 38, 1142-1153. [CrossRef] [PubMed]

41. Zhao, Y.; Shao, F. The NAIP-NLRC4 inflammasome in innate immune detection of bacterial flagellin and type III secretion apparatus. Immunol. Rev. 2015, 265, 85-102. [CrossRef] [PubMed]

42. Zhang, L.; Chen, S.; Ruan, J.; Wu, J.; Tong, A.B.; Yin, Q.; Li, Y.; David, L.; Lu, A.; Wang, W.L.; et al. Cryo-EM structure of the activated NAIP2-NLRC4 inflammasome reveals nucleated polymerization. Science 2015, 350, 404-409. [CrossRef] [PubMed]

43. Hu, Z.; Zhou, Q.; Zhang, C.; Fan, S.; Cheng, W.; Zhao, Y.; Shao, F.; Wang, H.-W.; Sui, S.-F.; Chai, J. Structural and biochemical basis for induced self-propagation of NLRC4. Science 2015, 350, 399-404. [CrossRef] [PubMed]

44. Xiao, T.S. The nucleic acid-sensing inflammasomes. Immunol. Rev. 2015, 265, 103-111. [CrossRef] [PubMed]

45. Roberts, T.L.; Idris, A.; Dunn, J.A.; Kelly, G.M.; Burnton, C.M.; Hodgson, S.; Hardy, L.L.; Garceau, V.; Sweet, M.J.; Ross, I.L.; et al. HIN-200 proteins regulate caspase activation in response to foreign cytoplasmic DNA. Science 2009, 323, 1057-1060. [CrossRef] [PubMed]

46. Yin, Q.; Sester, D.P.; Tian, Y.; Hsiao, Y.-S.; Lu, A.; Cridland, J.A.; Sagulenko, V.; Thygesen, S.J.; Choubey, D.; Hornung, V.; et al. Molecular mechanism for p202-mediated specific inhibition of AIM2 inflammasome activation. Cell Rep. 2013, 4, 327-339. [CrossRef] [PubMed]

47. Zhao, Y.; Shao, F. Diverse mechanisms for inflammasome sensing of cytosolic bacteria and bacterial virulence. Curr. Opin. Microbiol. 2016, 29, 37-42. [CrossRef] [PubMed]

48. Kayagaki, N.; Stowe, I.B.; Lee, B.L.; O’Rourke, K.; Anderson, K.; Warming, S.; Cuellar, T.; Haley, B.; Roose-Girma, M.; Phung, Q.T.; et al. Caspase-11 cleaves gasdermin D for non-canonical inflammasome signalling. Nature 2015, 526, 666-671. [CrossRef] [PubMed]

49. Shi, J.; Zhao, Y.; Wang, K.; Shi, X.; Wang, Y.; Huang, H.; Zhuang, Y.; Cai, T.; Wang, F.; Shao, F. Cleavage of GSDMD by inflammatory caspases determines pyroptotic cell death. Nature 2015, 526, 660-665. [CrossRef] [PubMed] 
50. Lin, M.; Rikihisa, Y. Ehrlichia chaffeensis and Anaplasma phagocytophilum lack genes for lipid A biosynthesis and incorporate cholesterol for their survival. Infect. Immun. 2003, 71, 5324-5331. [CrossRef] [PubMed]

51. Takayama, K.; Rothenberg, R.J.; Barbour, A.G. Absence of lipopolysaccharide in the Lyme disease spirochete, Borrelia burgdorferi. Infect. Immun. 1987, 55, 2311-2313. [PubMed]

52. Amano, K.; Tamura, A.; Ohashi, N.; Urakami, H.; Kaya, S.; Fukushi, K. Deficiency of peptidoglycan and lipopolysaccharide components in Rickettsia tsutsugamushi. Infect. Immun. 1987, 55, 2290-2292. [PubMed]

53. Min, C.-K.; Yang, J.-S.; Kim, S.; Choi, M.-S.; Kim, I.-S.; Cho, N.-H. Genome-based construction of the metabolic pathways of Orientia tsutsugamushi and comparative analysis within the Rickettsiales order. Comp. Funct. Genom. 2008, 623145.

54. Gunn, J.S.; Ernst, R.K. The structure and function of Francisella lipopolysaccharide. Ann. N. Y. Acad. Sci. 2007, 1105, 202-218. [CrossRef] [PubMed]

55. Steere, A.C. Lyme disease. N. Engl. J. Med. 2001, 345, 115-125. [CrossRef] [PubMed]

56. Steere, A.C.; Sikand, V.K. The presenting manifestations of Lyme disease and the outcomes of treatment. N. Engl. J. Med. 2003, 348, 2472-2474. [CrossRef] [PubMed]

57. Kleinnijenhuis, J.; Joosten, L.A.B.; van de Veerdonk, F.L.; Savage, N.; van Crevel, R.; Kullberg, B.J.; van der Ven, A.; Ottenhoff, T.H.M.; Dinarello, C.A.; van der Meer, J.W.M.; et al. Transcriptional and inflammasome-mediated pathways for the induction of IL-1 $\beta$ production by Mycobacterium tuberculosis. Eur. J. Immunol. 2009, 39, 1914-1922. [CrossRef] [PubMed]

58. Carlsson, F.; Kim, J.; Dumitru, C.; Barck, K.H.; Carano, R.A.D.; Sun, M.; Diehl, L.; Brown, E.J. Host-detrimental role of Esx-1-mediated inflammasome activation in mycobacterial infection. PLoS Pathog. 2010, 6, e1000895. [CrossRef] [PubMed]

59. Yang, Y.; Zhou, X.; Kouadir, M.; Shi, F.; Ding, T.; Liu, C.; Liu, J.; Wang, M.; Yang, L.; Yin, X.; et al. The AIM2 inflammasome is involved in macrophage activation during infection with virulent Mycobacterium bovis strain. J. Infect. Dis. 2013, 208, 1849-1858. [CrossRef] [PubMed]

60. Koo, I.C.; Wang, C.; Raghavan, S.; Morisaki, J.H.; Cox, J.S.; Brown, E.J. ESX-1-dependent cytolysis in lysosome secretion and inflammasome activation during mycobacterial infection. Cell. Microbiol. 2008, 10, 1866-1878. [CrossRef] [PubMed]

61. Boyden, E.D.; Dietrich, W.F. Nalp1b controls mouse macrophage susceptibility to anthrax lethal toxin. Nat. Genet. 2006, 38, 240-244. [CrossRef] [PubMed]

62. Neiman-Zenevich, J.; Liao, K.-C.; Mogridge, J. Distinct regions of NLRP1B are required to respond to anthrax lethal toxin and metabolic inhibition. Infect. Immun. 2014, 82, 3697-3703. [CrossRef] [PubMed]

63. Chavarría-Smith, J.; Vance, R.E. Direct proteolytic cleavage of NLRP1B is necessary and sufficient for inflammasome activation by anthrax lethal factor. PLoS Pathog. 2013, 9, e1003452. [CrossRef] [PubMed]

64. Levinsohn, J.L.; Newman, Z.L.; Hellmich, K.A.; Fattah, R.; Getz, M.A.; Liu, S.; Sastalla, I.; Leppla, S.H.; Moayeri, M. Anthrax lethal factor cleavage of Nlrp1 is required for activation of the inflammasome. PLoS Pathog. 2012, 8, e1002638. [CrossRef] [PubMed]

65. Fink, S.L.; Bergsbaken, T.; Cookson, B.T. Anthrax lethal toxin and Salmonella elicit the common cell death pathway of caspase-1-dependent pyroptosis via distinct mechanisms. Proc. Natl. Acad. Sci. USA 2008, 105, 4312-4317. [CrossRef] [PubMed]

66. Hellmich, K.A.; Levinsohn, J.L.; Fattah, R.; Newman, Z.L.; Maier, N.; Sastalla, I.; Liu, S.; Leppla, S.H.; Moayeri, M. Anthrax lethal factor cleaves mouse Nlrp1b in both toxin-sensitive and toxin-resistant macrophages. PLoS ONE 2012, 7, e49741. [CrossRef] [PubMed]

67. Abdul-Sater, A.A.; Koo, E.; Häcker, G.; Ojcius, D.M. Inflammasome-dependent caspase-1 activation in cervical epithelial cells stimulates growth of the intracellular pathogen Chlamydia trachomatis. J. Biol. Chem. 2009, 284, 26789-26796. [CrossRef] [PubMed]

68. Shimada, K.; Crother, T.R.; Arditi, M. Innate immune responses to Chlamydia pneumoniae infection: Role of TLRs, NLRs, and the inflammasome. Microbes Infect. Inst. Pasteur 2012, 14, 1301-1307. [CrossRef] [PubMed]

69. He, X.; Mekasha, S.; Mavrogiorgos, N.; Fitzgerald, K.A.; Lien, E.; Ingalls, R.R. Inflammation and fibrosis during Chlamydia pneumoniae infection is regulated by IL-1 and the NLRP3/ASC inflammasome. J. Immunol. 2010, 184, 5743-5754. [CrossRef] [PubMed]

70. Brumell, J.H.; Tang, P.; Zaharik, M.L.; Finlay, B.B. Disruption of the Salmonella-containing vacuole leads to increased replication of Salmonella enterica serovar Typhimurium in the cytosol of epithelial cells. Infect. Immun. 2002, 70, 3264-3270. [CrossRef] [PubMed] 
71. Zhao, Y.; Yang, J.; Shi, J.; Gong, Y.-N.; Lu, Q.; Xu, H.; Liu, L.; Shao, F. The NLRC4 inflammasome receptors for bacterial flagellin and type III secretion apparatus. Nature 2011, 477, 596-600. [CrossRef] [PubMed]

72. Yang, J.; Zhao, Y.; Shi, J.; Shao, F. Human NAIP and mouse NAIP1 recognize bacterial type III secretion needle protein for inflammasome activation. Proc. Natl. Acad. Sci. USA 2013, 110, 14408-14413. [CrossRef] [PubMed]

73. Kortmann, J.; Brubaker, S.W.; Monack, D.M. Cutting edge: Inflammasome activation in primary human macrophages is dependent on flagellin. J. Immunol. 2015, 195, 815-819. [CrossRef] [PubMed]

74. Qu, Y.; Misaghi, S.; Newton, K.; Maltzman, A.; Izrael-Tomasevic, A.; Arnott, D.; Dixit, V.M. NLRP3 recruitment by NLRC4 during Salmonella infection. J. Exp. Med. 2016, 213, 877-885. [CrossRef] [PubMed]

75. Casson, C.N.; Shin, S. Inflammasome-mediated cell death in response to bacterial pathogens that access the host cell cytosol: Lessons from Legionella pneumophila. Front. Cell. Infect. Microbiol. 2013, 3. [CrossRef] [PubMed]

76. Growney, J.D.; Dietrich, W.F. High-resolution genetic and physical map of the Lgn1 interval in C57BL/6J implicates Naip2 or Naip5 in Legionella pneumophila pathogenesis. Genome Res. 2000, 10, 1158-1171. [CrossRef] [PubMed]

77. Diez, E.; Lee, S.-H.; Gauthier, S.; Yaraghi, Z.; Tremblay, M.; Vidal, S.; Gros, P. Birc1e is the gene within the Lgn1 locus associated with resistance to Legionella pneumophila. Nat. Genet. 2003, 33, 55-60. [CrossRef] [PubMed]

78. Wright, E.K.; Goodart, S.A.; Growney, J.D.; Hadinoto, V.; Endrizzi, M.G.; Long, E.M.; Sadigh, K.; Abney, A.L.; Bernstein-Hanley, I.; Dietrich, W.F. Naip5 affects host susceptibility to the intracellular pathogen Legionella pneumophila. Curr. Biol. 2003, 13, 27-36. [CrossRef]

79. Derré, I.; Isberg, R.R. Macrophages from mice with the restrictive Lgn1 allele exhibit multifactorial resistance to Legionella pneumophila. Infect. Immun. 2004, 72, 6221-6229. [CrossRef] [PubMed]

80. Zamboni, D.S.; Kobayashi, K.S.; Kohlsdorf, T.; Ogura, Y.; Long, E.M.; Vance, R.E.; Kuida, K.; Mariathasan, S.; Dixit, V.M.; Flavell, R.A.; et al. The Bircle cytosolic pattern-recognition receptor contributes to the detection and control of Legionella pneumophila infection. Nat. Immunol. 2006, 7, 318-325. [CrossRef] [PubMed]

81. Kofoed, E.M.; Vance, R.E. Innate immune recognition of bacterial ligands by NAIPs determines inflammasome specificity. Nature 2011, 477, 592-595. [CrossRef] [PubMed]

82. Molofsky, A.B.; Byrne, B.G.; Whitfield, N.N.; Madigan, C.A.; Fuse, E.T.; Tateda, K.; Swanson, M.S. Cytosolic recognition of flagellin by mouse macrophages restricts Legionella pneumophila infection. J. Exp. Med. 2006, 203, 1093-1104. [CrossRef] [PubMed]

83. Ren, T.; Zamboni, D.S.; Roy, C.R.; Dietrich, W.F.; Vance, R.E. Flagellin-deficient Legionella mutants evade caspase-1- and Naip5-mediated macrophage immunity. PLoS Pathog. 2006, 2, e18. [CrossRef] [PubMed]

84. Amer, A.; Franchi, L.; Kanneganti, T.-D.; Body-Malapel, M.; Ozören, N.; Brady, G.; Meshinchi, S.; Jagirdar, R.; Gewirtz, A.; Akira, S.; et al. Regulation of Legionella phagosome maturation and infection through flagellin and host Ipaf. J. Biol. Chem. 2006, 281, 35217-35223. [CrossRef] [PubMed]

85. Fortier, A.; de Chastellier, C.; Balor, S.; Gros, P. Birc1e/Naip5 rapidly antagonizes modulation of phagosome maturation by Legionella pneumophila. Cell. Microbiol. 2007, 9, 910-923. [CrossRef] [PubMed]

86. Akhter, A.; Gavrilin, M.A.; Frantz, L.; Washington, S.; Ditty, C.; Limoli, D.; Day, C.; Sarkar, A.; Newland, C.; Butchar, J.; et al. Caspase-7 activation by the Nlrc4/Ipaf inflammasome restricts Legionella pneumophila infection. PLoS Pathog. 2009, 5, e1000361. [CrossRef] [PubMed]

87. Case, C.L.; Shin, S.; Roy, C.R. Asc and Ipaf Inflammasomes direct distinct pathways for caspase-1 activation in response to Legionella pneumophila. Infect. Immun. 2009, 77, 1981-1991. [CrossRef] [PubMed]

88. Case, C.L.; Kohler, L.J.; Lima, J.B.; Strowig, T.; de Zoete, M.R.; Flavell, R.A.; Zamboni, D.S.; Roy, C.R. Caspase-11 stimulates rapid flagellin-independent pyroptosis in response to Legionella pneumophila. Proc. Natl. Acad. Sci. USA 2013, 110, 1851-1856. [CrossRef] [PubMed]

89. Casson, C.N.; Copenhaver, A.M.; Zwack, E.E.; Nguyen, H.T.; Strowig, T.; Javdan, B.; Bradley, W.P.; Fung, T.C.; Flavell, R.A.; Brodsky, I.E.; et al. Caspase-11 activation in response to bacterial secretion systems that access the host cytosol. PLoS Pathog. 2013, 9, e1003400. [CrossRef] [PubMed]

90. Marlovits, T.C.; Kubori, T.; Sukhan, A.; Thomas, D.R.; Galán, J.E.; Unger, V.M. Structural insights into the assembly of the type III secretion needle complex. Science 2004, 306, 1040-1042. [CrossRef] [PubMed] 
91. Sani, M.; Allaoui, A.; Fusetti, F.; Oostergetel, G.T.; Keegstra, W.; Boekema, E.J. Structural organization of the needle complex of the type III secretion apparatus of Shigella flexneri. Micron (Oxf. Engl. 1993) 2007, 38, 291-301. [CrossRef] [PubMed]

92. Suzuki, S.; Franchi, L.; He, Y.; Muñoz-Planillo, R.; Mimuro, H.; Suzuki, T.; Sasakawa, C.; Núñez, G. Shigella type III secretion protein MxiI is recognized by Naip2 to induce Nlrc4 inflammasome activation independently of Pkcס. PLoS Pathog 2014, 10, e1003926. [CrossRef] [PubMed]

93. Suzuki, S.; Mimuro, H.; Kim, M.; Ogawa, M.; Ashida, H.; Toyotome, T.; Franchi, L.; Suzuki, M.; Sanada, T.; Suzuki, T.; et al. Shigella IpaH7.8 E3 ubiquitin ligase targets glomulin and activates inflammasomes to demolish macrophages. Proc. Natl. Acad. Sci. USA 2014, 111, E4254-E4263. [CrossRef] [PubMed]

94. Tobe, T.; Beatson, S.A.; Taniguchi, H.; Abe, H.; Bailey, C.M.; Fivian, A.; Younis, R.; Matthews, S.; Marches, O.; Frankel, G.; et al. An extensive repertoire of type III secretion effectors in Escherichia coli $\mathrm{O} 157$ and the role of lambdoid phages in their dissemination. Proc. Natl. Acad. Sci. USA 2006, 103, 14941-14946. [CrossRef] [PubMed]

95. Iguchi, A.; Thomson, N.R.; Ogura, Y.; Saunders, D.; Ooka, T.; Henderson, I.R.; Harris, D.; Asadulghani, M.; Kurokawa, K.; Dean, P.; et al. Complete genome sequence and comparative genome analysis of enteropathogenic Escherichia coli O127:H6 strain E2348/69. J. Bacteriol. 2009, 191, 347-354. [CrossRef] [PubMed]

96. Kayagaki, N.; Warming, S.; Lamkanfi, M.; Vande Walle, L.; Louie, S.; Dong, J.; Newton, K.; Qu, Y.; Liu, J.; Heldens, S.; et al. Non-canonical inflammasome activation targets caspase-11. Nature 2011, 479, 117-121. [CrossRef] [PubMed]

97. Rathinam, V.A.K.; Vanaja, S.K.; Waggoner, L.; Sokolovska, A.; Becker, C.; Stuart, L.M.; Leong, J.M.; Fitzgerald, K.A. TRIF licenses caspase-11-dependent NLRP3 inflammasome activation by gram-negative bacteria. Cell 2012, 150, 606-619. [CrossRef] [PubMed]

98. Yen, H.; Sugimoto, N.; Tobe, T. Enteropathogenic Escherichia coli uses NleA to inhibit NLRP3 inflammasome activation. PLoS Pathog. 2015, 11. [CrossRef] [PubMed]

99. Franchi, L.; Stoolman, J.; Kanneganti, T.-D.; Verma, A.; Ramphal, R.; Núñez, G. Critical role for Ipaf in Pseudomonas aeruginosa-induced caspase-1 activation. Eur. J. Immunol. 2007, 37, 3030-3039. [CrossRef] [PubMed]

100. Miao, E.A.; Ernst, R.K.; Dors, M.; Mao, D.P.; Aderem, A. Pseudomonas aeruginosa activates caspase 1 through Ipaf. Proc. Natl. Acad. Sci. USA 2008, 105, 2562-2567. [CrossRef] [PubMed]

101. Sutterwala, F.S.; Mijares, L.A.; Li, L.; Ogura, Y.; Kazmierczak, B.I.; Flavell, R.A. Immune recognition of Pseudomonas aeruginosa mediated by the IPAF/NLRC4 inflammasome. J. Exp. Med. 2007, 204, 3235-3245. [CrossRef] [PubMed]

102. Arlehamn, C.S.L.; Evans, T.J. Pseudomonas aeruginosa pilin activates the inflammasome. Cell. Microbiol. 2011, 13, 388-401. [CrossRef] [PubMed]

103. Jabir, M.S.; Hopkins, L.; Ritchie, N.D.; Ullah, I.; Bayes, H.K.; Li, D.; Tourlomousis, P.; Lupton, A.; Puleston, D.; Simon, A.K.; et al. Mitochondrial damage contributes to Pseudomonas aeruginosa activation of the inflammasome and is downregulated by autophagy. Autophagy 2015, 11, 166-182. [CrossRef] [PubMed]

104. Wu, J.; Fernandes-Alnemri, T.; Alnemri, E.S. Involvement of the AIM2, NLRC4, and NLRP3 inflammasomes in caspase-1 activation by Listeria monocytogenes. J. Clin. Immunol. 2010, 30, 693-702. [CrossRef] [PubMed]

105. Li, W.; Chang, Y.; Liang, S.; Zhong, Z.; Li, X.; Wen, J.; Zhang, Y.; Zhang, J.; Wang, L.; Lin, H.; et al. NLRP3 inflammasome activation contributes to Listeria monocytogenes-induced animal pregnancy failure. BMC Vet. Res. 2016, 12. [CrossRef] [PubMed]

106. Meixenberger, K.; Pache, F.; Eitel, J.; Schmeck, B.; Hippenstiel, S.; Slevogt, H.; N'Guessan, P.; Witzenrath, M.; Netea, M.G.; Chakraborty, T.; et al. Listeria monocytogenes-infected human peripheral blood mononuclear cells produce IL-1 $\beta$, depending on Listeriolysin O and NLRP3. J. Immunol. 2010, 184, 922-930. [CrossRef] [PubMed]

107. Wang, X.; Shaw, D.K.; Hammond, H.L.; Sutterwala, F.S.; Rayamajhi, M.; Shirey, K.A.; Perkins, D.J.; Bonventre, J.V.; Velayutham, T.S.; Evans, S.M.; et al. The prostaglandin E2-EP3 receptor axis regulates Anaplasma phagocytophilum-mediated NLRC4 inflammasome activation. PLoS Pathog. 2016, 12, e1005803. [CrossRef] [PubMed] 
108. Sukumaran, B.; Ogura, Y.; Pedra, J.H.F.; Kobayashi, K.S.; Flavell, R.A.; Fikrig, E. Receptor interacting protein-2 contributes to host defense against Anaplasma phagocytophilum infection. FEMS Immunol. Med. Microbiol. 2012, 66, 211-219. [CrossRef] [PubMed]

109. Chen, G.; Severo, M.S.; Sohail, M.; Sakhon, O.S.; Wikel, S.K.; Kotsyfakis, M.; Pedra, J.H. Ixodes scapularis saliva mitigates inflammatory cytokine secretion during Anaplasma phagocytophilum stimulation of immune cells. Parasites Vectors 2012, 5, 229. [CrossRef] [PubMed]

110. Chen, G.; Wang, X.; Severo, M.S.; Sakhon, O.S.; Sohail, M.; Brown, L.J.; Sircar, M.; Snyder, G.A.; Sundberg, E.J.; Ulland, T.K.; et al. The tick salivary protein Sialostatin L2 inhibits caspase-1-mediated inflammation during Anaplasma phagocytophilum infection. Infect. Immun. 2014, 82, 2553-2564. [CrossRef] [PubMed]

111. Cruz, A.R.; Moore, M.W.; La Vake, C.J.; Eggers, C.H.; Salazar, J.C.; Radolf, J.D. Phagocytosis of Borrelia burgdorferi, the Lyme disease spirochete, potentiates innate immune activation and induces apoptosis in human monocytes. Infect. Immun. 2008, 76, 56-70. [CrossRef] [PubMed]

112. Liu, N.; Belperron, A.A.; Booth, C.J.; Bockenstedt, L.K. The Caspase 1 inflammasome is not required for control of murine Lyme borreliosis. Infect. Immun. 2009, 77, 3320-3327. [CrossRef] [PubMed]

113. Oosting, M.; van de Veerdonk, F.L.; Kanneganti, T.-D.; Sturm, P.; Verschueren, I.; Berende, A.; van der Meer, J.W.M.; Kullberg, B.-J.; Netea, M.G.; Joosten, L.A.B. Borrelia species induce inflammasome activation and IL-17 production through a caspase-1-dependent mechanism. Eur. J. Immunol. 2011, 41, 172-181. [CrossRef] [PubMed]

114. Oosting, M.; Buffen, K.; Malireddi, S.R.; Sturm, P.; Verschueren, I.; Koenders, M.I.; van de Veerdonk, F.L.; van der Meer, J.W.; Netea, M.G.; Kanneganti, T.-D.; et al. Murine Borrelia arthritis is highly dependent on ASC and caspase-1, but independent of NLRP3. Arthritis Res. Ther. 2012, 14, R247. [CrossRef] [PubMed]

115. Chattoraj, P.; Yang, Q.; Khandai, A.; Al-Hendy, O.; Ismail, N. TLR2 and Nod2 mediate resistance or susceptibility to fatal intracellular Ehrlichiai infection in murine models of ehrlichiosis. PLoS ONE 2013, 8. [CrossRef] [PubMed]

116. Yang, Q.; Stevenson, H.L.; Scott, M.J.; Ismail, N. Type I interferon contributes to noncanonical inflammasome activation, mediates immunopathology, and impairs protective immunity during fatal infection with lipopolysaccharide-legative Ehrlichiae. Am. J. Pathol. 2015, 185, 446-461. [CrossRef] [PubMed]

117. Meunier, E.; Wallet, P.; Dreier, R.F.; Costanzo, S.; Anton, L.; Rühl, S.; Dussurgey, S.; Dick, M.S.; Kistner, A.; Rigard, M.; et al. Guanylate-binding proteins promote activation of the AIM2 inflammasome during infection with Francisella novicida. Nat. Immunol. 2015, 16, 476-484. [CrossRef] [PubMed]

118. Fernandes-Alnemri, T.; Yu, J.-W.; Juliana, C.; Solorzano, L.; Kang, S.; Wu, J.; Datta, P.; McCormick, M.; Huang, L.; McDermott, E.; et al. The AIM2 inflammasome is critical for innate immunity to Francisella tularensis. Nat. Immunol. 2010, 11, 385-393. [CrossRef] [PubMed]

119. Smalley, C.; Bechelli, J.; Rockx-Brouwer, D.; Saito, T.; Azar, S.R.; Ismail, N.; Walker, D.H.; Fang, R. Rickettsia australis activates inflammasome in human and murine macrophages. PLoS ONE 2016, 11, e0157231. [CrossRef] [PubMed]

120. Lima-Junior, D.S.; Costa, D.L.; Carregaro, V.; Cunha, L.D.; Silva, A.L.N.; Mineo, T.W.P.; Gutierrez, F.R.S.; Bellio, M.; Bortoluci, K.R.; Flavell, R.A.; et al. Inflammasome-derived IL-1 $\beta$ production induces nitric oxide-mediated resistance to Leishmania. Nat. Med. 2013, 19, 909-915. [CrossRef] [PubMed]

121. Zamboni, D.S.; Lima-Junior, D.S. Inflammasomes in host response to protozoan parasites. Immunol. Rev. 2015, 265, 156-171. [CrossRef] [PubMed]

122. Lefèvre, L.; Lugo-Villarino, G.; Meunier, E.; Valentin, A.; Olagnier, D.; Authier, H.; Duval, C.; Dardenne, C.; Bernad, J.; Lemesre, J.L.; et al. The C-type lectin receptors dectin-1, MR, and SIGNR3 contribute both positively and negatively to the macrophage response to Leishmania infantum. Immunity 2013, 38, 1038-1049. [CrossRef] [PubMed]

123. Silva, G.K.; Costa, R.S.; Silveira, T.N.; Caetano, B.C.; Horta, C.V.; Gutierrez, F.R.S.; Guedes, P.M.M.; Andrade, W.A.; de Niz, M.; Gazzinelli, R.T.; et al. Apoptosis-associated speck-like protein containing a caspase recruitment domain inflammasomes mediate IL-1 $\beta$ response and host resistance to Trypanosoma cruzi infection. J. Immunol. 2013, 191, 3373-3383. [CrossRef] [PubMed]

124. Gonçalves, V.M.; Matteucci, K.C.; Buzzo, C.L.; Miollo, B.H.; Ferrante, D.; Torrecilhas, A.C.; Rodrigues, M.M.; Alvarez, J.M.; Bortoluci, K.R. NLRP3 controls Trypanosoma cruzi infection through a caspase-1-dependent IL-1R-independent NO production. PLoS Negl. Trop. Dis. 2013, 7, e2469. 
125. Shio, M.T.; Tiemi, S.M.; Eisenbarth, S.C.; Savaria, M.; Vinet, A.F.; Bellemare, M.-J.; Harder, K.W.; Sutterwala, F.S.; Bohle, D.S.; Descoteaux, A.; et al. Malarial hemozoin activates the NLRP3 inflammasome through Lyn and Syk kinases. PLoS Pathog. 2009, 5, e1000559. [CrossRef]

126. Dostert, C.; Guarda, G.; Romero, J.F.; Menu, P.; Gross, O.; Tardivel, A.; Suva, M.-L.; Stehle, J.-C.; Kopf, M.; Stamenkovic, I.; et al. Malarial hemozoin is a Nalp3 inflammasome activating danger signal. PLoS ONE 2009, 4, e6510. [CrossRef] [PubMed]

127. Ataide, M.A.; Andrade, W.A.; Zamboni, D.S.; Wang, D.; Souza, M.C.; Franklin, B.S.; Elian, S.; Martins, F.S.; Pereira, D.; Reed, G.; et al. Malaria-induced NLRP12/NLRP3-dependent caspase-1 activation mediates inflammation and hypersensitivity to bacterial superinfection. PLoS Pathog. 2014, 10, e1003885. [CrossRef] [PubMed]

128. Kalantari, P.; DeOliveira, R.B.; Chan, J.; Corbett, Y.; Rathinam, V.; Stutz, A.; Latz, E.; Gazzinelli, R.T.; Golenbock, D.T.; Fitzgerald, K.A. Dual engagement of the NLRP3 and AIM2 inflammasomes by plasmodium-derived hemozoin and DNA during malaria. Cell Rep. 2014, 6, 196-210. [CrossRef] [PubMed]

129. Dutra, F.F.; Alves, L.S.; Rodrigues, D.; Fernandez, P.L.; de Oliveira, R.B.; Golenbock, D.T.; Zamboni, D.S.; Bozza, M.T. Hemolysis-induced lethality involves inflammasome activation by heme. Proc. Natl. Acad. Sci. USA 2014, 111, E4110-E4118. [CrossRef] [PubMed]

130. Ritter, M.; Gross, O.; Kays, S.; Ruland, J.; Nimmerjahn, F.; Saijo, S.; Tschopp, J.; Layland, L.E.; Prazeres da Costa, C. Schistosoma mansoni triggers Dectin-2, which activates the Nlrp3 inflammasome and alters adaptive immune responses. Proc. Natl. Acad. Sci. USA 2010, 107, 20459-20464. [CrossRef] [PubMed]

131. Ferguson, B.J.; Newland, S.A.; Gibbs, S.E.; Tourlomousis, P.; Fernandes dos Santos, P.; Patel, M.N.; Hall, S.W.; Walczak, H.; Schramm, G.; Haas, H.; et al. The Schistosoma mansoni T2 ribonuclease omega-1 modulates inflammasome-dependent IL-1 $\beta$ secretion in macrophages. Int. J. Parasitol. 2015, 45, 809-813. [CrossRef] [PubMed]

132. Wu, D.-L.; Xu, G.-H.; Lu, S.-M.; Ma, B.-L.; Miao, N.-Z.; Liu, X.-B.; Cheng, Y.; Feng, J.-H.; Liu, Z.-G.; Feng-Ding; et al. Correlation of AIM2 expression in peripheral blood mononuclear cells from humans with acute and chronic hepatitis B. Hum. Immunol. 2013, 74, 514-521. [CrossRef] [PubMed]

133. Burdette, D.; Haskett, A.; Presser, L.; McRae, S.; Iqbal, J.; Waris, G. Hepatitis C virus activates interleukin-1 $\beta$ via caspase-1-inflammasome complex. J. Gen. Virol. 2012, 93, 235-246. [CrossRef] [PubMed]

134. Negash, A.A.; Ramos, H.J.; Crochet, N.; Lau, D.T.Y.; Doehle, B.; Papic, N.; Delker, D.A.; Jo, J.; Bertoletti, A.; Hagedorn, C.H.; et al. IL-1 $\beta$ production through the NLRP3 inflammasome by hepatic macrophages links hepatitis C virus infection with liver inflammation and disease. PLoS Pathog. 2013, 9, e1003330. [CrossRef] [PubMed]

135. Chattergoon, M.A.; Latanich, R.; Quinn, J.; Winter, M.E.; Buckheit, R.W.; Blankson, J.N.; Pardoll, D.; Cox, A.L. $\mathrm{HIV}$ and $\mathrm{HCV}$ activate the inflammasome in monocytes and macrophages via endosomal Toll-like receptors without induction of type 1 interferon. PLoS Pathog. 2014, 10, e1004082. [CrossRef] [PubMed]

136. Hornung, V.; Ablasser, A.; Charrel-Dennis, M.; Bauernfeind, F.; Horvath, G.; Caffrey, D.R.; Latz, E.; Fitzgerald, K.A. AIM2 recognizes cytosolic dsDNA and forms a caspase-1-activating inflammasome with ASC. Nature 2009, 458, 514-518. [CrossRef] [PubMed]

137. Segovia, J.; Sabbah, A.; Mgbemena, V.; Tsai, S.-Y.; Chang, T.-H.; Berton, M.T.; Morris, I.R.; Allen, I.C.; Ting, J.P.-Y.; Bose, S. TLR2/MyD88/NF-kB pathway, reactive oxygen species, potassium efflux activates NLRP3/ASC inflammasome during respiratory syncytial virus infection. PLoS ONE 2012, 7, e29695. [CrossRef] [PubMed]

138. Triantafilou, K.; Kar, S.; van Kuppeveld, F.J.M.; Triantafilou, M. Rhinovirus-induced calcium flux triggers NLRP3 and NLRC5 activation in bronchial cells. Am. J. Respir. Cell Mol. Biol. 2013, 49, 923-934. [CrossRef] [PubMed]

139. Callaway, J.B.; Smith, S.A.; McKinnon, K.P.; de Silva, A.M.; Crowe, J.E.; Ting, J.P.-Y. Spleen tyrosine kinase (Syk) mediates IL-1 $\beta$ induction by primary human monocytes during antibody-enhanced Dengue virus infection. J. Biol. Chem. 2015, 290, 17306-17320. [CrossRef] [PubMed]

140. Hottz, E.D.; Lopes, J.F.; Freitas, C.; Valls-de-Souza, R.; Oliveira, M.F.; Bozza, M.T.; Da Poian, A.T.; Weyrich, A.S.; Zimmerman, G.A.; Bozza, F.A.; et al. Platelets mediate increased endothelium permeability in dengue through NLRP3-inflammasome activation. Blood 2013, 122, 3405-3414. [CrossRef] [PubMed] 
141. Wikan, N.; Khongwichit, S.; Phuklia, W.; Ubol, S.; Thonsakulprasert, T.; Thannagith, M.; Tanramluk, D.; Paemanee, A.; Kittisenachai, S.; Roytrakul, S.; et al. Comprehensive proteomic analysis of white blood cells from Chikungunya fever patients of different severities. J. Transl. Med. 2014, 12, 96. [CrossRef] [PubMed]

142. Ekchariyawat, P.; Hamel, R.; Bernard, E.; Wichit, S.; Surasombatpattana, P.; Talignani, L.; Thomas, F.; Choumet, V.; Yssel, H.; Desprès, P.; et al. Inflammasome signaling pathways exert antiviral effect against Chikungunya virus in human dermal fibroblasts. Infect. Genet. Evol. J. Mol. Epidemiol. Evol. Genet. Infect. Dis. 2015, 32, 401-408. [CrossRef] [PubMed]

143. Pontillo, A.; Brandão, L.A.; Guimarães, R.L.; Segat, L.; Athanasakis, E.; Crovella, S. A 3'UTR SNP in NLRP3 gene is associated with susceptibility to HIV-1 infection. J. Acquir. Immune Defic. Syndr. 2010, 54, 236-240. [CrossRef] [PubMed]

144. Pontillo, A.; Oshiro, T.M.; Girardelli, M.; Kamada, A.J.; Crovella, S.; Duarte, A.J.S. Polymorphisms in inflammasome' genes and susceptibility to HIV-1 infection. J. Acquir. Immune Defic. Syndr. 2012, 59, 121-125. [CrossRef] [PubMed]

145. Guo, H.; Gao, J.; Taxman, D.J.; Ting, J.P.Y.; Su, L. HIV-1 infection induces interleukin-1 $\beta$ production via TLR8 protein-dependent and NLRP3 inflammasome mechanisms in human monocytes. J. Biol. Chem. 2014, 289, 21716-21726. [CrossRef] [PubMed]

146. Allen, I.C.; Scull, M.A.; Moore, C.B.; Holl, E.K.; McElvania-TeKippe, E.; Taxman, D.J.; Guthrie, E.H.; Pickles, R.J.; Ting, J.P.-Y. The NLRP3 inflammasome mediates in vivo innate immunity to Influenza A virus through recognition of viral RNA. Immunity 2009, 30, 556-565. [CrossRef] [PubMed]

147. Ichinohe, T.; Pang, I.K.; Iwasaki, A. Influenza virus activates inflammasomes via its intracellular M2 ion channel. Nat. Immunol. 2010, 11, 404-410. [CrossRef] [PubMed]

148. Strittmatter, G.E.; Sand, J.; Sauter, M.; Seyffert, M.; Steigerwald, R.; Fraefel, C.; Smola, S.; French, L.E.; Beer, H.-D. IFN- $\gamma$ primes keratinocytes for HSV-1-induced inflammasome activation. J. Investig. Dermatol. 2016, 136, 610-620. [CrossRef] [PubMed]

149. Rivera-Chávez, F.; Bäumler, A.J. The pyromaniac inside you: Salmonella metabolism in the host gut. Annu. Rev. Microbiol. 2015, 69, 31-48. [CrossRef] [PubMed]

150. Hilbi, H.; Hoffmann, C.; Harrison, C.F. Legionella spp. outdoors: Colonization, communication and persistence. Environ. Microbiol. Rep. 2011, 3, 286-296. [CrossRef] [PubMed]

151. Newton, H.J.; Ang, D.K.Y.; van Driel, I.R.; Hartland, E.L. Molecular pathogenesis of infections caused by Legionella pneumophila. Clin. Microbiol. Rev. 2010, 23, 274-298. [CrossRef] [PubMed]

152. Hoffmann, C.; Harrison, C.F.; Hilbi, H. The natural alternative: Protozoa as cellular models for Legionella infection. Cell. Microbiol. 2014, 16, 15-26. [CrossRef] [PubMed]

153. Kümpers, P.; Tiede, A.; Kirschner, P.; Girke, J.; Ganser, A.; Peest, D. Legionnaires' disease in immunocompromised patients: A case report of Legionella longbeachae pneumonia and review of the literature. J. Med. Microbiol. 2008, 57, 384-387. [CrossRef] [PubMed]

154. Amodeo, M.R.; Murdoch, D.R.; Pithie, A.D. Legionnaires' disease caused by Legionella longbeachae and Legionella pneumophila: Comparison of clinical features, host-related risk factors, and outcomes. Clin. Microbiol. Infect. 2010, 16, 1405-1407. [CrossRef] [PubMed]

155. Hubber, A.; Roy, C.R. Modulation of host cell function by Legionella pneumophila type IV effectors. Annu. Rev. Cell Dev. Biol. 2010, 26, 261-283. [CrossRef] [PubMed]

156. Akhter, A.; Caution, K.; Abu Khweek, A.; Tazi, M.; Abdulrahman, B.A.; Abdelaziz, D.H.A.; Voss, O.H.; Doseff, A.I.; Hassan, H.; Azad, A.K.; et al. Caspase-11 promotes the fusion of phagosomes harboring pathogenic bacteria with lysosomes by modulating actin polymerization. Immunity 2012, 37, $35-47$. [CrossRef] [PubMed]

157. Creasey, E.A.; Isberg, R.R. The protein SdhA maintains the integrity of the Legionella-containing vacuole. Proc. Natl. Acad. Sci. USA 2012, 109, 3481-3486. [CrossRef] [PubMed]

158. Monroe, K.M.; McWhirter, S.M.; Vance, R.E. Identification of host cytosolic sensors and bacterial factors regulating the type I interferon response to Legionella pneumophila. PLoS Pathog. 2009, 5, e1000665. [CrossRef] [PubMed]

159. Ge, J.; Gong, Y.-N.; Xu, Y.; Shao, F. Preventing bacterial DNA release and absent in melanoma 2 inflammasome activation by a Legionella effector functioning in membrane trafficking. Proc. Natl. Acad. Sci. USA 2012, 109, 6193-6198. [CrossRef] [PubMed] 
160. Aachoui, Y.; Leaf, I.A.; Hagar, J.A.; Fontana, M.F.; Campos, C.G.; Zak, D.E.; Tan, M.H.; Cotter, P.A.; Vance, R.E.; Aderem, A.; et al. Caspase-11 protects against bacteria that escape the vacuole. Science 2013, 339, 975-978. [CrossRef] [PubMed]

161. Belland, R.; Ojcius, D.M.; Byrne, G.I. Focus: Chlamydia. Nat. Rev. Microbiol. 2004, 2, 530-531. [CrossRef] [PubMed]

162. Roulis, E.; Polkinghorne, A.; Timms, P. Chlamydia pneumoniae: Modern insights into an ancient pathogen. Trends Microbiol. 2013, 21, 120-128. [CrossRef] [PubMed]

163. Hafner, L.M. Pathogenesis of fallopian tube damage caused by Chlamydia trachomatis infections. Contraception 2015, 92, 108-115. [CrossRef] [PubMed]

164. Mueller, K.E.; Plano, G.V.; Fields, K.A. New frontiers in type III secretion biology: The Chlamydia perspective. Infect. Immun. 2014, 82, 2-9. [CrossRef] [PubMed]

165. Jorgensen, I.; Bednar, M.M.; Amin, V.; Davis, B.K.; Ting, J.P.Y.; McCafferty, D.G.; Valdivia, R.H. The Chlamydia protease CPAF regulates host and bacterial proteins to maintain pathogen vacuole integrity and promote virulence. Cell Host Microbe 2011, 10, 21-32. [CrossRef] [PubMed]

166. Cheng, W.; Shivshankar, P.; Li, Z.; Chen, L.; Yeh, I.-T.; Zhong, G. Caspase-1 contributes to Chlamydia trachomatis-induced upper urogenital tract inflammatory pathologies without affecting the course of infection. Infect. Immun. 2008, 76, 515-522. [CrossRef] [PubMed]

167. Finethy, R.; Jorgensen, I.; Haldar, A.K.; de Zoete, M.R.; Strowig, T.; Flavell, R.A.; Yamamoto, M.; Nagarajan, U.M.; Miao, E.A.; Coers, J. Guanylate binding proteins enable rapid activation of canonical and noncanonical inflammasomes in Chlamydia-infected macrophages. Infect. Immun. 2015, 83, 4740-4749. [CrossRef] [PubMed]

168. Alderwick, L.J.; Harrison, J.; Lloyd, G.S.; Birch, H.L. The Mycobacterial cell wall-Peptidoglycan and arabinogalactan. Cold Spring Harb. Perspect. Med. 2015, 5, a021113. [CrossRef] [PubMed]

169. Rohde, K.; Yates, R.M.; Purdy, G.E.; Russell, D.G. Mycobacterium tuberculosis and the environment within the phagosome. Immunol. Rev. 2007, 219, 37-54. [CrossRef] [PubMed]

170. Meena, L.S. Rajni Survival mechanisms of pathogenic Mycobacterium tuberculosis H37Rv. FEBS J. 2010, 277, 2416-2427. [CrossRef] [PubMed]

171. Mayer-Barber, K.D.; Barber, D.L.; Shenderov, K.; White, S.D.; Wilson, M.S.; Cheever, A.; Kugler, D.; Hieny, S.; Caspar, P.; Núñez, G.; et al. Caspase-1 independent IL-1beta production is critical for host resistance to Mycobacterium tuberculosis and does not require TLR signaling in vivo. J. Immunol. 2010, 184, 3326-3330. [CrossRef] [PubMed]

172. Mayer-Barber, K.D.; Andrade, B.B.; Barber, D.L.; Hieny, S.; Feng, C.G.; Caspar, P.; Oland, S.; Gordon, S.; Sher, A. Innate and adaptive interferons suppress IL- $1 \alpha$ and IL-1 $\beta$ production by distinct pulmonary myeloid subsets during Mycobacterium tuberculosis infection. Immunity 2011, 35, 1023-1034. [CrossRef] [PubMed]

173. McElvania Tekippe, E.; Allen, I.C.; Hulseberg, P.D.; Sullivan, J.T.; McCann, J.R.; Sandor, M.; Braunstein, M.; Ting, J.P.-Y. Granuloma formation and host defense in chronic Mycobacterium tuberculosis infection requires PYCARD/ASC but not NLRP3 or caspase-1. PLoS ONE 2010, 5, e12320. [CrossRef] [PubMed]

174. Fremond, C.M.; Togbe, D.; Doz, E.; Rose, S.; Vasseur, V.; Maillet, I.; Jacobs, M.; Ryffel, B.; Quesniaux, V.F.J. IL-1 Receptor-mediated signal is an essential component of MyD88-dependent innate response to Mycobacterium tuberculosis infection. J. Immunol. 2007, 179, 1178-1189. [CrossRef] [PubMed]

175. Schneider, B.E.; Korbel, D.; Hagens, K.; Koch, M.; Raupach, B.; Enders, J.; Kaufmann, S.H.E.; Mittrücker, H.-W.; Schaible, U.E. A role for IL-18 in protective immunity against Mycobacterium tuberculosis. Eur. J. Immunol. 2010, 40, 396-405. [CrossRef] [PubMed]

176. Briken, V.; Ahlbrand, S.E.; Shah, S. Mycobacterium tuberculosis and the host cell inflammasome: A complex relationship. Front. Cell. Infect. Microbiol. 2013, 3, 62. [CrossRef] [PubMed]

177. Kurenuma, T.; Kawamura, I.; Hara, H.; Uchiyama, R.; Daim, S.; Dewamitta, S.R.; Sakai, S.; Tsuchiya, K.; Nomura, T.; Mitsuyama, M. The RD1 locus in the Mycobacterium tuberculosis genome contributes to activation of caspase-1 via induction of potassium ion efflux in infected macrophages. Infect. Immun. 2009, 77, 3992-4001. [CrossRef] [PubMed]

178. Chen, C.-C.; Tsai, S.-H.; Lu, C.-C.; Hu, S.-T.; Wu, T.-S.; Huang, T.-T.; Saïd-Sadier, N.; Ojcius, D.M.; Lai, H.-C. Activation of an NLRP3 inflammasome restricts Mycobacterium kansasii infection. PLoS ONE 2012, 7, e36292. [CrossRef] [PubMed] 
179. Dorhoi, A.; Nouailles, G.; Jörg, S.; Hagens, K.; Heinemann, E.; Pradl, L.; Oberbeck-Müller, D.; Duque-Correa, M.A.; Reece, S.T.; Ruland, J.; et al. Activation of the NLRP3 inflammasome by Mycobacterium tuberculosis is uncoupled from susceptibility to active tuberculosis. Eur. J. Immunol. 2012, 42, 374-384. [CrossRef] [PubMed]

180. Lee, H.-M.; Yuk, J.-M.; Kim, K.-H.; Jang, J.; Kang, G.; Park, J.B.; Son, J.-W.; Jo, E.-K. Mycobacterium abscessus activates the NLRP3 inflammasome via Dectin-1-Syk and p62/SQSTM1. Immunol. Cell Biol. 2012, 90, 601-610. [CrossRef] [PubMed]

181. Lee, H.-M.; Kang, J.; Lee, S.J.; Jo, E.-K. Microglial activation of the NLRP3 inflammasome by the priming signals derived from macrophages infected with mycobacteria. Glia 2013, 61, 441-452. [CrossRef] [PubMed]

182. Saiga, H.; Kitada, S.; Shimada, Y.; Kamiyama, N.; Okuyama, M.; Makino, M.; Yamamoto, M.; Takeda, K. Critical role of AIM2 in Mycobacterium tuberculosis infection. Int. Immunol. 2012, 24, 637-644. [CrossRef] [PubMed]

183. Shah, S.; Bohsali, A.; Ahlbrand, S.E.; Srinivasan, L.; Rathinam, V.A.K.; Vogel, S.N.; Fitzgerald, K.A.; Sutterwala, F.S.; Briken, V. Cutting Edge: Mycobacterium tuberculosis but Not Nonvirulent Mycobacteria Inhibits IFN- $\beta$ and AIM2 Inflammasome-Dependent IL-1 $\beta$ Production via Its ESX-1 Secretion System. J. Immunol. 2013, 191, 3514-3518. [CrossRef] [PubMed]

184. Khan, N.; Vidyarthi, A.; Javed, S.; Agrewala, J.N. Innate immunity holding the glanks until reinforced by adaptive immunity against Mycobacterium tuberculosis infection. Front. Microbiol. 2016, 7, 328. [CrossRef] [PubMed]

185. Ghoreschi, K.; Laurence, A.; Yang, X.-P.; Tato, C.M.; McGeachy, M.J.; Konkel, J.E.; Ramos, H.L.; Wei, L.; Davidson, T.S.; Bouladoux, N.; et al. Generation of pathogenic T(H)17 cells in the absence of TGF- $\beta$ signalling. Nature 2010, 467, 967-971. [CrossRef] [PubMed]

186. Khan, N.; Vidyarthi, A.; Pahari, S.; Negi, S.; Aqdas, M.; Nadeem, S.; Agnihotri, T.; Agrewala, J.N. Signaling through NOD-2 and TLR-4 bolsters the T cell priming capability of dendritic cells by inducing autophagy. Sci. Rep. 2016, 6, 19084. [CrossRef] [PubMed]

187. Khader, S.A.; Cooper, A.M. IL-23 and IL-17 in tuberculosis. Cytokine 2008, 41, 79-83. [CrossRef] [PubMed]

188. Miller, L.H.; Ackerman, H.C.; Su, X.; Wellems, T.E. Malaria biology and disease pathogenesis: Insights for new treatments. Nat. Med. 2013, 19, 156-167. [CrossRef] [PubMed]

189. Grau, G.E.; Heremans, H.; Piguet, P.F.; Pointaire, P.; Lambert, P.H.; Billiau, A.; Vassalli, P. Monoclonal antibody against interferon gamma can prevent experimental cerebral malaria and its associated overproduction of tumor necrosis factor. Proc. Natl. Acad. Sci. USA 1989, 86, 5572-5574. [CrossRef] [PubMed]

190. Franklin, B.S.; Parroche, P.; Ataíde, M.A.; Lauw, F.; Ropert, C.; de Oliveira, R.B.; Pereira, D.; Tada, M.S.; Nogueira, P.; da Silva, L.H.P.; et al. Malaria primes the innate immune response due to interferon- $\gamma$ induced enhancement of Toll-like receptor expression and function. Proc. Natl. Acad. Sci. USA 2009, 106, 5789-5794. [CrossRef] [PubMed]

191. Kwiatkowski, D.; Hill, A.V.; Sambou, I.; Twumasi, P.; Castracane, J.; Manogue, K.R.; Cerami, A.; Brewster, D.R.; Greenwood, B.M. TNF concentration in fatal cerebral, non-fatal cerebral, and uncomplicated Plasmodium falciparum malaria. Lancet Lond. Engl. 1990, 336, 1201-1204. [CrossRef]

192. Olivier, M.; Van Den Ham, K.; Shio, M.T.; Kassa, F.A.; Fougeray, S. Malarial pigment hemozoin and the innate inflammatory response. Mol. Innate Immun. 2014, 5, 25. [CrossRef] [PubMed]

193. Coban, C.; Ishii, K.J.; Kawai, T.; Hemmi, H.; Sato, S.; Uematsu, S.; Yamamoto, M.; Takeuchi, O.; Itagaki, S.; Kumar, N.; et al. Toll-like receptor 9 mediates innate immune activation by the malaria pigment hemozoin. J. Exp. Med. 2005, 201, 19-25. [CrossRef] [PubMed]

194. Parroche, P.; Lauw, F.N.; Goutagny, N.; Latz, E.; Monks, B.G.; Visintin, A.; Halmen, K.A.; Lamphier, M.; Olivier, M.; Bartholomeu, D.C.; et al. Malaria hemozoin is immunologically inert but radically enhances innate responses by presenting malaria DNA to Toll-like receptor 9. Proc. Natl. Acad. Sci. USA 2007, 104, 1919-1924. [CrossRef] [PubMed]

195. Kordes, M.; Matuschewski, K.; Hafalla, J.C.R. Caspase-1 activation of interleukin-1 $\beta$ (IL-1 $\beta$ ) and IL-18 is dispensable for induction of experimental cerebral malaria. Infect. Immun. 2011, 79, 3633-3641. [CrossRef] [PubMed]

196. Labbé, K.; Miu, J.; Yeretssian, G.; Serghides, L.; Tam, M.; Finney, C.A.; Erdman, L.K.; Goulet, M.-L.; Kain, K.C.; Stevenson, M.M.; et al. Caspase-12 dampens the immune response to malaria independently of the inflammasome by targeting NF-kB signaling. J. Immunol. 2010, 185, 5495-5502. [CrossRef] [PubMed] 
197. Reimer, T.; Shaw, M.H.; Franchi, L.; Coban, C.; Ishii, K.J.; Akira, S.; Horii, T.; Rodriguez, A.; Núñez, G. Experimental cerebral malaria progresses independently of the Nlrp3 inflammasome. Eur. J. Immunol. 2010, 40, 764-769. [CrossRef] [PubMed]

198. Cunnington, A.J.; de Souza, J.B.; Walther, M.; Riley, E.M. Malaria impairs resistance to Salmonella through heme- and heme oxygenase-dependent dysfunctional granulocyte mobilization. Nat. Med. 2012, 18, 120-127. [CrossRef] [PubMed]

199. Scott, J.A.G.; Berkley, J.A.; Mwangi, I.; Ochola, L.; Uyoga, S.; Macharia, A.; Ndila, C.; Lowe, B.S.; Mwarumba, S.; Bauni, E.; et al. Relation between falciparum malaria and bacteraemia in Kenyan children: A population-based, case-control study and a longitudinal study. Lancet 2011, 378, 1316-1323. [CrossRef]

200. Were, T.; Davenport, G.C.; Hittner, J.B.; Ouma, C.; Vulule, J.M.; Ong'echa, J.M.; Perkins, D.J. Bacteremia in Kenyan children presenting with malaria. J. Clin. Microbiol. 2011, 49, 671-676. [CrossRef] [PubMed]

201. Sonenshine, D.E.; Roe, R.M. (Eds.) Biology of Ticks, 2nd ed.; Oxford University Press: New York, NY, USA, 2014; Volume 2.

202. Champion, C.I.; Blanco, D.R.; Skare, J.T.; Haake, D.A.; Giladi, M.; Foley, D.; Miller, J.N.; Lovett, M.A. A 9.0-kilobase-pair circular plasmid of Borrelia burgdorferi encodes an exported protein: Evidence for expression only during infection. Infect. Immun. 1994, 62, 2653-2661. [PubMed]

203. Schwan, T.G.; Piesman, J.; Golde, W.T.; Dolan, M.C.; Rosa, P.A. Induction of an outer surface protein on Borrelia burgdorferi during tick feeding. Proc. Natl. Acad. Sci. USA 1995, 92, 2909-2913. [CrossRef] [PubMed]

204. Akins, D.R.; Porcella, S.F.; Popova, T.G.; Shevchenko, D.; Baker, S.I.; Li, M.; Norgard, M.V.; Radolf, J.D. Evidence for in vivo but not in vitro expression of a Borrelia burgdorferi outer surface protein $\mathrm{F}(\mathrm{OspF})$ homologue. Mol. Microbiol. 1995, 18, 507-520. [CrossRef] [PubMed]

205. Stevenson, B.; Schwan, T.G.; Rosa, P.A. Temperature-related differential expression of antigens in the Lyme disease spirochete, Borrelia burgdorferi. Infect. Immun. 1995, 63, 4535-4539. [PubMed]

206. Das, S.; Barthold, S.W.; Giles, S.S.; Montgomery, R.R.; Telford, S.R.; Fikrig, E. Temporal pattern of Borrelia burgdorferi p21 expression in ticks and the mammalian host. J. Clin. Investig. 1997, 99, 987-995. [CrossRef] [PubMed]

207. Fikrig, E.; Barthold, S.W.; Sun, W.; Feng, W.; Telford, S.R.; Flavell, R.A. Borrelia burgdorferi P35 and P37 proteins, expressed in vivo, elicit protective immunity. Immunity 1997, 6, 531-539. [CrossRef]

208. Cassatt, D.R.; Patel, N.K.; Ulbrandt, N.D.; Hanson, M.S. DbpA, but not OspA, is expressed by Borrelia burgdorferi during spirochetemia and is a target for protective antibodies. Infect. Immun. 1998, 66, 5379-5387. [PubMed]

209. Carroll, J.A.; Garon, C.F.; Schwan, T.G. Effects of environmental pH on membrane proteins in Borrelia burgdorferi. Infect. Immun. 1999, 67, 3181-3187. [PubMed]

210. Skare, J.T.; Foley, D.M.; Hernandez, S.R.; Moore, D.C.; Blanco, D.R.; Miller, J.N.; Lovett, M.A. Cloning and molecular characterization of plasmid-encoded antigens of Borrelia burgdorferi. Infect. Immun. 1999, 67, 4407-4417. [PubMed]

211. Yang, X.; Goldberg, M.S.; Popova, T.G.; Schoeler, G.B.; Wikel, S.K.; Hagman, K.E.; Norgard, M.V. Interdependence of environmental factors influencing reciprocal patterns of gene expression in virulent Borrelia burgdorferi. Mol. Microbiol. 2000, 37, 1470-1479. [CrossRef] [PubMed]

212. Revel, A.T.; Talaat, A.M.; Norgard, M.V. DNA microarray analysis of differential gene expression in Borrelia burgdorferi, the Lyme disease spirochete. Proc. Natl. Acad. Sci. USA 2002, 99, 1562-1567. [CrossRef] [PubMed]

213. Ojaimi, C.; Brooks, C.; Casjens, S.; Rosa, P.; Elias, A.; Barbour, A.; Jasinskas, A.; Benach, J.; Katona, L.; Radolf, J.; et al. Profiling of temperature-induced changes in Borrelia burgdorferi gene expression by using whole genome arrays. Infect. Immun. 2003, 71, 1689-1705. [CrossRef] [PubMed]

214. Ojaimi, C.; Mulay, V.; Liveris, D.; Iyer, R.; Schwartz, I. Comparative transcriptional profiling of Borrelia burgdorferi clinical isolates differing in capacities for hematogenous dissemination. Infect. Immun. 2005, 73, 6791-6802. [CrossRef] [PubMed]

215. Brooks, C.S.; Hefty, P.S.; Jolliff, S.E.; Akins, D.R. Global Analysis of Borrelia burgdorferi genes regulated by mammalian host-specific signals. Infect. Immun. 2003, 71, 3371-3383. [CrossRef] [PubMed]

216. Seshu, J.; Boylan, J.A.; Gherardini, F.C.; Skare, J.T. Dissolved oxygen levels alter gene expression and antigen profiles in Borrelia burgdorferi. Infect. Immun. 2004, 72, 1580-1586. [CrossRef] [PubMed] 
217. Tokarz, R.; Anderton, J.M.; Katona, L.I.; Benach, J.L. Combined effects of blood and temperature shift on Borrelia burgdorferi gene expression as determined by whole genome DNA array. Infect. Immun. 2004, 72, 5419-5432. [CrossRef] [PubMed]

218. Hyde, J.A.; Trzeciakowski, J.P.; Skare, J.T. Borrelia burgdorferi alters its gene expression and antigenic profile in response to $\mathrm{CO}_{2}$ levels. J. Bacteriol. 2007, 189, 437-445. [CrossRef] [PubMed]

219. Lybecker, M.C.; Samuels, D.S. Temperature-induced regulation of RpoS by a small RNA in Borrelia burgdorferi. Mol. Microbiol. 2007, 64, 1075-1089. [CrossRef] [PubMed]

220. Korch, G.W. Geographic dissemination of tick-borne zoonoses. In Ecological Dynamics of Tick-Borne Zoonoses; Sonenshine, D., Mather, T., Eds.; Oxford University Press: New York, NY, USA, 1994; pp. 139-197.

221. McCoy, K.D.; Léger, E.; Dietrich, M. Host specialization in ticks and transmission of tick-borne diseases: A review. Front. Cell. Infect. Microbiol. 2013, 3, 57. [CrossRef] [PubMed]

222. Wikel, S. Ticks and tick-borne pathogens at the cutaneous interface: Host defenses, tick countermeasures, and a suitable environment for pathogen establishment. Front. Microbiol. 2013, 4, 337. [CrossRef] [PubMed]

223. Gherardini, F.; Boylan, J.; Lawrence, K.; Skare, J. Metabolism and Physiology of Borrelia. In Borrelia: Molecular Biology, Host Interaction and Pathogenesis; Samuels, D., Radolf, J., Eds.; Caister Academic Press: Virginia, VA, USA, 2010; pp. 103-138.

224. Boylan, J.A.; Lawrence, K.A.; Downey, J.S.; Gherardini, F.C. Borrelia burgdorferi membranes are the primary targets of reactive oxygen species. Mol. Microbiol. 2008, 68, 786-799. [CrossRef] [PubMed]

225. Chmelař, J.; Kotál, J.; Kopecký, J.; Pedra, J.H.F.; Kotsyfakis, M. All for one and one for all on the tick-host battlefield. Trends Parasitol. 2016, 32, 368-377. [CrossRef] [PubMed]

226. Kotál, J.; Langhansová, H.; Lieskovská, J.; Andersen, J.F.; Francischetti, I.M.B.; Chavakis, T.; Kopecký, J.; Pedra, J.H.F.; Kotsyfakis, M.; Chmelař, J. Modulation of host immunity by tick saliva. J. Proteom. 2015, 128, 58-68. [CrossRef] [PubMed]

227. Kazimírová, M.; Štibrániová, I. Tick salivary compounds: Their role in modulation of host defenses and pathogen transmission. Front. Cell. Infect. Microbiol. 2013, 3, 43. [CrossRef] [PubMed]

228. Gillespie, R.D.; Dolan, M.C.; Piesman, J.; Titus, R.G. Identification of an IL-2 binding protein in the saliva of the Lyme disease vector tick, Ixodes scapularis. J. Immunol. 2001, 166, 4319-4326. [CrossRef] [PubMed]

229. Guo, X.; Booth, C.J.; Paley, M.A.; Wang, X.; DePonte, K.; Fikrig, E.; Narasimhan, S.; Montgomery, R.R. Inhibition of neutrophil function by two tick salivary proteins. Infect. Immun. 2009, 77, 2320-2329. [CrossRef] [PubMed]

230. Paesen, G.C.; Adams, P.L.; Harlos, K.; Nuttall, P.A.; Stuart, D.I. Tick histamine-binding proteins: Isolation, cloning, and three-dimensional structure. Mol. Cell 1999, 3, 661-671. [CrossRef]

231. Poole, N.M.; Mamidanna, G.; Smith, R.A.; Coons, L.B.; Cole, J.A. Prostaglandin E2 in tick saliva regulates macrophage cell migration and cytokine profile. Parasites Vectors 2013, 6, 261. [CrossRef] [PubMed]

232. Kramer, C.D.; Poole, N.M.; Coons, L.B.; Cole, J.A. Tick saliva regulates migration, phagocytosis, and gene expression in the macrophage-like cell line, IC-21. Exp. Parasitol. 2011, 127, 665-671. [CrossRef] [PubMed]

233. Sonenshine, D.E.; Roe, R.M. (Eds.) Biology of Ticks, 1st ed.; Oxford University Press: New York, NY, USA, 2014; Volume 1.

234. Chmelar, J.; Oliveira, C.J.; Rezacova, P.; Francischetti, I.M.B.; Kovarova, Z.; Pejler, G.; Kopacek, P.; Ribeiro, J.M.C.; Mares, M.; Kopecky, J.; et al. A tick salivary protein targets cathepsin G and chymase and inhibits host inflammation and platelet aggregation. Blood 2011, 117, 736-744. [CrossRef] [PubMed]

235. Chmelař, J.; Kotál, J.; Karim, S.; Kopacek, P.; Francischetti, I.M.B.; Pedra, J.H.F.; Kotsyfakis, M. Sialomes and mialomes: A systems-biology view of tick tissues and tick-host interactions. Trends Parasitol. 2016, 32, 242-254. [CrossRef] [PubMed]

236. Fuchsberger, N.; Kita, M.; Hajnicka, V.; Imanishi, J.; Labuda, M.; Nuttall, P.A. Ixodid tick salivary gland extracts inhibit production of lipopolysaccharide-induced mRNA of several different human cytokines. Exp. Appl. Acarol. 1995, 19, 671-676. [CrossRef] [PubMed]

237. Hovius, J.W.R. Spitting image: Tick saliva assists the causative agent of Lyme disease in evading host skin's innate immune response. J. Investig. Dermatol. 2009, 129, 2337-2339. [CrossRef] [PubMed]

238. Mans, B.J. Evolution of vertebrate hemostatic and inflammatory control mechanisms in blood-feeding arthropods. J. Innate Immun. 2011, 3, 41-51. [CrossRef] [PubMed] 
239. Oliveira, C.J.F.; Sá-Nunes, A.; Francischetti, I.M.B.; Carregaro, V.; Anatriello, E.; Silva, J.S.; de Miranda Santos, I.K.F.; Ribeiro, J.M.C.; Ferreira, B.R. Deconstructing tick saliva. J. Biol. Chem. 2011, 286, 10960-10969. [CrossRef] [PubMed]

240. Ramachandra, R.N.; Wikel, S.K. Modulation of host-immune responses by ticks (Acari: Ixodidae): Effect of salivary gland extracts on host macrophages and lymphocyte cytokine production. J. Med. Entomol. 1992, 29, 818-826. [CrossRef] [PubMed]

241. Ribeiro, J.M. Role of saliva in tick/host interactions. Exp. Appl. Acarol. 1989, 7, 15-20. [CrossRef] [PubMed]

242. Ribeiro, J.M. Role of saliva in blood-feeding by arthropods. Annu. Rev. Entomol. 1987, 32, 463-478. [CrossRef] [PubMed]

243. Ribeiro, J.M.; Makoul, G.T.; Levine, J.; Robinson, D.R.; Spielman, A. Antihemostatic, antiinflammatory, and immunosuppressive properties of the saliva of a tick, Ixodes dammini. J. Exp. Med. 1985, 161, 332-344. [CrossRef] [PubMed]

244. Ribeiro, J.M.C.; Francischetti, I.M.B. Role of arthropod saliva in blood feeding: Sialome and post-sialome perspectives. Annu. Rev. Entomol. 2003, 48, 73-88. [CrossRef] [PubMed]

245. Steen, N.A.; Barker, S.C.; Alewood, P.F. Proteins in the saliva of the Ixodida (ticks): Pharmacological features and biological significance. Toxicon Off. J. Int. Soc. Toxinol. 2006, 47, 1-20. [CrossRef] [PubMed]

246. Stibrániová, I.; Lahová, M.; Bartíková, P. Immunomodulators in tick saliva and their benefits. Acta Virol. 2013, 57, 200-216. [CrossRef] [PubMed]

247. Wikel, S.K. Host immunity to ticks. Annu. Rev. Entomol. 1996, 41, 1-22. [CrossRef] [PubMed]

248. Wikel, S.K.; Bergman, D. Tick-host immunology: Significant advances and challenging opportunities. Parasitol. Today 1997, 13, 383-389. [CrossRef]

249. Kuthejlová, M.; Kopecký, J.; Štěpánová, G.; Macela, A. Tick salivary gland extract inhibits killing of Borrelia afzelii spirochetes by mouse macrophages. Infect. Immun. 2001, 69, 575-578. [CrossRef] [PubMed]

250. Kýcková, K.; Kopecký, J. Effect of tick saliva on mechanisms of innate immune response against Borrelia afzelii. J. Med. Entomol. 2006, 43, 1208-1214. [CrossRef]

251. Menten-Dedoyart, C.; Faccinetto, C.; Golovchenko, M.; Dupiereux, I.; Van Lerberghe, P.-B.; Dubois, S.; Desmet, C.; Elmoualij, B.; Baron, F.; Rudenko, N.; et al. Neutrophil extracellular traps entrap and kill Borrelia burgdorferi sensu stricto spirochetes and are not affected by Ixodes ricinus tick saliva. J. Immunol. 2012, 189, 5393-5401. [CrossRef] [PubMed]

252. Ribeiro, J.M.; Weis, J.J.; Telford, S.R. Saliva of the tick Ixodes dammini inhibits neutrophil function. Exp. Parasitol. 1990, 70, 382-388. [CrossRef]

253. Turni, C.; Lee, R.P.; Jackson, L.A. Effect of salivary gland extracts from the tick, Boophilus microplus, on leucocytes from Brahman and Hereford cattle. Parasite Immunol. 2002, 24, 355-361. [CrossRef] [PubMed]

254. Langhansová, H.; Bopp, T.; Schmitt, E.; Kopecký, J. Tick saliva increases production of three chemokines including monocyte chemoattractant protein-1, a histamine-releasing cytokine. Parasite Immunol. 2015, 37, 92-96. [CrossRef] [PubMed]

255. Hannier, S.; Liversidge, J.; Sternberg, J.M.; Bowman, A.S. Ixodes ricinus tick salivary gland extract inhibits IL-10 secretion and CD69 expression by mitogen-stimulated murine splenocytes and induces hyporesponsiveness in B lymphocytes. Parasite Immunol. 2003, 25, 27-37. [CrossRef] [PubMed]

256. Lieskovská, J.; Páleníková, J.; Širmarová, J.; Elsterová, J.; Kotsyfakis, M.; Campos Chagas, A.; Calvo, E.; R ůžek, D.; Kopecký, J. Tick salivary cystatin sialostatin L2 suppresses IFN responses in mouse dendritic cells. Parasite Immunol. 2015, 37, 70-78. [CrossRef] [PubMed]

257. Lieskovská, J.; Páleníková, J.; Langhansová, H.; Chagas, A.C.; Calvo, E.; Kotsyfakis, M.; Kopecký, J. Tick Sialostatins L and L2 differentially influence dendritic cell responses to Borrelia spirochetes. Parasites Vectors 2015, 8, 275. [CrossRef] [PubMed]

258. Sá-Nunes, A.; Bafica, A.; Lucas, D.A.; Conrads, T.P.; Veenstra, T.D.; Andersen, J.F.; Mather, T.N.; Ribeiro, J.M.C.; Francischetti, I.M.B. Prostaglandin E2 is a major inhibitor of dendritic cell maturation and function in Ixodes scapularis saliva. J. Immunol. 2007, 179, 1497-1505. [CrossRef] [PubMed]

259. Schuijt, T.J.; Narasimhan, S.; Daffre, S.; DePonte, K.; Hovius, J.W.R.; Van't Veer, C.; van der Poll, T.; Bakhtiari, K.; Meijers, J.C.M.; Boder, E.T.; et al. Identification and characterization of Ixodes scapularis antigens that elicit tick immunity using yeast surface display. PLoS ONE 2011, 6, e15926. [CrossRef] [PubMed] 
260. Schuijt, T.J.; Coumou, J.; Narasimhan, S.; Dai, J.; Deponte, K.; Wouters, D.; Brouwer, M.; Oei, A.; Roelofs, J.J.T.H.; van Dam, A.P.; et al. A tick mannose-binding lectin inhibitor interferes with the vertebrate complement cascade to enhance transmission of the Lyme disease agent. Cell Host Microbe 2011, 10, 136-146. [CrossRef] [PubMed]

261. Tyson, K.; Elkins, C.; Patterson, H.; Fikrig, E.; de Silva, A. Biochemical and functional characterization of Salp20, an Ixodes scapularis tick salivary protein that inhibits the complement pathway. Insect Mol. Biol. 2007, 16, 469-479. [CrossRef] [PubMed]

262. Tyson, K.R.; Elkins, C.; de Silva, A.M. A novel mechanism of complement inhibition unmasked by a tick salivary protein that binds to properdin. J. Immunol. 2008, 180, 3964-3968. [CrossRef] [PubMed]

263. Bowman, A.S.; Coons, L.B.; Needham, G.R.; Sauer, J.R. Tick saliva: Recent advances and implications for vector competence. Med. Vet. Entomol. 1997, 11, 277-285. [CrossRef] [PubMed]

264. Ramamoorthi, N.; Narasimhan, S.; Pal, U.; Bao, F.; Yang, X.F.; Fish, D.; Anguita, J.; Norgard, M.V.; Kantor, F.S.; Anderson, J.F.; et al. The Lyme disease agent exploits a tick protein to infect the mammalian host. Nature 2005, 436, 573-577. [CrossRef] [PubMed]

265. Nuttall, P.A.; Labuda, M. Saliva-assisted transmission of tick-borne pathogens. In Ticks; Bowman, A.S., Nuttall, P.A., Eds.; Cambridge University Press: Cambridge, UK, 2008; pp. 205-219.

266. Francischetti, I.M.; Sá-Nunes, A.; Mans, B.J.; Santos, I.M.; Ribeiro, J.M.C. The role of saliva in tick feeding. Front. Biosci. 2009, 14, 2051-2088. [CrossRef]

267. Shaw, D.K.; Kotsyfakis, M.; Pedra, J.H.F. For whom the bell tolls (and nods): Spit-acular saliva. Curr. Trop. Med. Rep. 2016, 3, 40-50. [CrossRef] [PubMed]

268. Pritt, B.S.; Sloan, L.M.; Johnson, D.K.H.; Munderloh, U.G.; Paskewitz, S.M.; McElroy, K.M.; McFadden, J.D.; Binnicker, M.J.; Neitzel, D.F.; Liu, G.; et al. Emergence of a new pathogenic Ehrlichia species, Wisconsin and Minnesota, 2009. N. Engl. J. Med. 2011, 365, 422-429. [CrossRef] [PubMed]

269. Gavrilin, M.A.; Wewers, M.D. Francisella Recognition by Inflammasomes: Differences between Mice and Men. Front. Microbiol. 2011, 2, 11. [CrossRef] [PubMed]

270. Jones, C.L.; Weiss, D.S. TLR2 signaling contributes to rapid inflammasome activation during F. novicida infection. PLoS ONE 2011, 6, e20609. [CrossRef] [PubMed]

271. Beck, G.; Benach, J.L.; Habicht, G.S. Isolation, preliminary chemical characterization, and biological activity of Borrelia burgdorferi peptidoglycan. Biochem. Biophys. Res. Commun. 1990, 167, 89-95. [CrossRef]

272. Truchan, H.K.; VieBrock, L.; Cockburn, C.L.; Ojogun, N.; Griffin, B.P.; Wijesinghe, D.S.; Chalfant, C.E.; Carlyon, J.A. Anaplasma phagocytophilum Rab10-dependent parasitism of the trans-Golgi network is critical for completion of the infection cycle. Cell. Microbiol. 2016, 18, 260-281. [CrossRef] [PubMed]

273. Rikihisa, Y. Mechanisms of obligatory intracellular infection with Anaplasma phagocytophilum. Clin. Microbiol. Rev. 2011, 24, 469-489. [CrossRef] [PubMed]

274. Mott, J.; Barnewall, R.E.; Rikihisa, Y. Human granulocytic ehrlichiosis agent and Ehrlichia chaffeensis reside in different cytoplasmic compartments in HL-60 cells. Infect. Immun. 1999, 67, 1368-1378. [PubMed]

275. Webster, P.; IJdo, J.W.; Chicoine, L.M.; Fikrig, E. The agent of human granulocytic ehrlichiosis resides in an endosomal compartment. J. Clin. Investig. 1998, 101, 1932-1941. [CrossRef] [PubMed]

276. Huang, B.; Hubber, A.; McDonough, J.A.; Roy, C.R.; Scidmore, M.A.; Carlyon, J.A. The Anaplasma phagocytophilum-occupied vacuole selectively recruits Rab-GTPases that are predominantly associated with recycling endosomes. Cell. Microbiol. 2010, 12, 1292-1307. [CrossRef] [PubMed]

277. Chen, G.; Severo, M.S.; Sakhon, O.S.; Choy, A.; Herron, M.J.; Felsheim, R.F.; Wiryawan, H.; Liao, J.; Johns, J.L.; Munderloh, U.G.; et al. Anaplasma phagocytophilum dihydrolipoamide dehydrogenase 1 affects host-derived immunopathology during microbial colonization. Infect. Immun. 2012, 80, 3194-3205. [CrossRef] [PubMed]

(C) 2016 by the authors; licensee MDPI, Basel, Switzerland. This article is an open access article distributed under the terms and conditions of the Creative Commons Attribution (CC-BY) license (http://creativecommons.org/licenses/by/4.0/). 